Elsevier required licence: (C) <2019>. This manuscript version is made available under the CC-BY-NCND 4.0 license http://creativecommons.org/licenses/by-nc-nd/4.0/

The definitive publisher version is available online at

[https://www.sciencedirect.com/science/article/pii/S0048969718340518?via\%3Dihub] 


\section{Implementation of a specific urban water management - Sponge City}

Thu Thuy Nguyen ${ }^{\mathrm{a}}$, Huu Hao Ngo ${ }^{\mathrm{a},}$, Wenshan Guo ${ }^{\mathrm{a}}$, Xiaochang C. Wang ${ }^{\mathrm{b}}$, Nanqi Ren ${ }^{\mathrm{c}}$ Guibai $\mathrm{Li}^{\mathrm{c}}$, Jie Ding ${ }^{\mathrm{c}}$, Heng Liang ${ }^{\mathrm{c}}$

${ }^{a}$ Center for Technology in Water and Wastewater, School of Civil and Environmental Engineering, University of Technology Sydney, Sydney, NSW 2007, Australia

${ }^{b}$ International S\&T Cooperation Center for Urban Alternative Water Resources Development, Key Lab of Environmental Engineering, Shaanxi Province, Xi'an University of Architecture and Technology, Xi'an 710055, China

${ }^{c}$ State Key Laboratory of Urban Water Resource and Environment (SKLUWRE), Harbin Institute of Technology, 73 Huanghe Road, Nangang District, Harbin, 150090, P.R. China

*Corresponding author: Huu Hao Ngo,E-mail: ngohuuhao121@gmail.com 


\section{Abstract}

Climate change, rapid urbanization and inappropriate urban planning policies in many countries have resulted in urban water-related problems, such as flooding disasters, water pollution and water shortages. To tackle these issues, the specific urban water management strategy known as Sponge City has been implemented in China since 2013. This is a complex method and one involving many challenges. This paper critically assesses the approaches associated with conventional urban water management. The Sponge City concept and its adoption are then scrutinized to comprehensively assess the limitations and opportunities. It emerges that Sponge City has four main principles, these being: urban water resourcing, ecological water management, green infrastructures, and urban permeable pavement. The uncertainties in Sponge City design and planning, and financial insufficiencies are the most serious problems that can risk the failure of the Sponge City concept. While significant barriers exist, the opportunities for implementing a Sponge City are evident. To obtain multiecosystem services of Sponge City, it should be implemented at the watershed scales and be flexible, depending on different decision levels or catchment characteristics. It is essential to apply an intelligent decision-making mechanism and consider the need for close cooperation between various agencies with which the central government can work. A suitable sized and harmonious Sponge City, ensuring a good balance between socio-economic development and environmental conservation, is the ideal.

Keywords - Sponge City, urban water management, barriers, green infrastructures, socioeconomic development, environmental conservation. 


\section{Introduction}

Water management is an essential aspect in the sustainable development of urban areas (Schaffer and Vollmer, 2010). Urban water-related problems have raised concerns worldwide among the scientific community (Marlow et al., 2013). Due to rapid urbanization and the extreme weather phenomenon, water issues now include more urban floods, over-exploitation of groundwater, urban water shortages, the wasting of rainwater resources, and water pollution (Jia et al., 2015; Marlow et al., 2013). For instance, the over-use of 'grey construction' such as concrete and asphalt in urban development has created impermeable surfaces that are not able to absorb water. This leads to urban floods. The construction of buildings in urban environments has been about accommodating the rapidly increasing populations moving to urban areas from the regions. This has resulted in the removal of natural rainwater-retaining infrastructure including woodlands, green spaces, natural lakes and wetlands for rainwater recycling processes. For instance, stormwater has been discharged as wastewater rather than being absorbed into the soil; it should be added to groundwater reserves to conserve water, or reused as water resources for sustaining people's lives, abodes and agricultural production.

Another major reason for water flooding hazards is the problem of maladaptive drainage systems in urbanized regions. The inappropriate management of urban stormwater is not only detrimental to people's health, but the aquatic ecosystems as well. The focus in the last few decades has been on reducing floods, but now a number of objectives need to be meet for water quality improvement and rainwater recycling. From an urban water perspective, many scientists have asserted that the current model of centralized urban drainages is inappropriate due to constraints associated with climate change, urbanization and social circumstances (Brown et al., 2009; Pahl-Wostl, 2007). Urban water flooding and pollution have been the subject of investigation in developed countries since the 1970s (Fletcher et al., 2014). A 
number of solutions are suggested to address water issues for urban areas including smart growth cities and green cities (Liu \& Jensen, 2018).

Scientists and policy-makers have proposed several concepts and theories for urban water planning. These include best management practices (BMPs), which were introduced in the United States in the 1970s (Fletcher et al., 2014; Scholz, 2006). At the same time, in the United Kingdom, sustainable urban drainage systems (SUDS) were devised for the purpose of addressing water pollution and flood hazards (Fletcher et al., 2014). Since the 1990s, the low impact development (LID) strategy was accepted not only in the United States, but in New Zealand as well (Chui et al., 2016; Fletcher et al., 2014; Mao et al., 2017). In Australia, which has experienced six development stages of urban water management, water sensitive city (WSC) or water sensitive urban design (WSUD) was initiated in the $21^{\text {st }}$ century to bring a range of benefits which not only protect the degradation of urban water resources, but also manage and recycle stormwater so that cities become sustainable, liveable and resilient (Brown et al., 2009; Ashley et al., 2013). However, these concepts and strategies are still very much in the development stage (Chan et al., 2018), and they have only been applied in smallscale contexts like experimental pilots and localized areas.

For developing countries like China, most urban areas have witnessed high density population growth, intensive expansion of impermeable roads and rooftops and pressures of water flood disasters in terms of climate change. Their urbanized areas with existing urban water management systems are struggling to cope with these issues. As such, a new approach to urban water management is essential for developing countries. The Sponge City program was launched in 2013-14 to address and overcome the above-mentioned issues ( $\mathrm{Li}$ et al., 2017) by delivering multiple advantages for urban communities to improve water runoff reduction, water quality enahancement, better water storage and mitigating greenhouse gas emissions (GHGs) (Wang et al., 2018). The ambition in China is to create a new kind of urban water management system known as the Sponge City. Many pilot Sponge City programs 
commenced in 2015 and 2016 with the Chinese government stating that approximately $70 \%$ of stormwater would be recyled from implementing measures to improve permeation, detention, storage, purification and drainage systems (Li et al., 2017). Additionally, the Chinese government has aimed to target $20 \%$ of its urban areas with the Sponge City concept by 2020 ; this will rise to $80 \%$ of city regions by 2030 .

The reason for implementing Sponge City projects is to mitigate the effects of urban development on natural ecosystems and solve urban water-related problems at the same time (Li et al., 2018; Wang et al., 2018). Some prevalent technologies applied in Sponge City construction are green roofs, green spaces, artifical rainwater wetlands, inflitration ponds and biological retention facilities and water-permeable paving (Chen et al., 2015; Chen, 2016; Jia et al., 2017; Li et al., 2017; Li et al., 2016; Li et al., 2018; Wu et al., 2017; Wu, 2015; Zhang \& Che, 2016). To realize the Sponge City concept, the Chinese government invested heavily in this program with thirty urban areas being selected as the pilot Sponge Cities from 2015 to 2016 (Chan et al., 2018; Li et al., 2017). Some previous studies illustrated the development of Sponge City, its challenges and opportunities. Recently, Chan et al. (2018) and Wang et al. (2018) summarize the objectives and influence of Sponge City implementation on urban water flooding and urban planning, Jia et al. (2017) have described the Sponge City technical approaches and problems encountered. Some papers noted the challenges and opportunities of Sponge City construction in China. These range from technical problems to public acceptance, financial issues and the overall legal framework (Li et al., 2017; Li et al., 2016; Li et al., 2018; Wang et al., 2017; Xia et al., 2017).

Unfortunately, comprehensive and systematic reviews of Sponge City's adoption and development process are rare; moreover, the proposed solutions for Sponge City's challenges and barriers are also inadequate. This paper aims to illustrate clearly some aspects: (1) understanding the evolution of urban water management throughout the world and in China, and in particular the drivers for Sponge City implementation in that country; (2) clearly 
explaining the Sponge City's principle concepts and their objective in terms of urbanization and climate change in China; (3) understanding the barriers to and uncertainties concerning Sponge City construction in China; (4) the state of feasible solutions for this kind of city, and (5) what the future of Sponge City development may be in the large-scale context. It is important to consider the practical implications for developing countries, where serious water scarity and flood problems are being experienced.

\section{Adoption of Sponge City}

\subsection{Drivers of implementation}

China is implementing Sponge Cities that predominantly aim to prevent urban flood disasters. There are three main factors causing urban flooding - climate change, urbanization and inappropriate urban planning carried out by city management (see Figure 1) (Jiang et al., 2018). According to Jiang et al. (2018), one of the leading factors causing floods in China is climate change, which leads to heavy high intensity rainfall events that in a short time can generate dangerous flooding situations. As well, climate change means frequent precipitation extremes that increase flood hazards. Another reason why flood disasters are occurring is due to rapid urbanization (Wang et al., 2018; Wang et al., 2016; Wang et al., 2017b; Xia et al., 2017b). During urbanization, natural lands are converted into residential or commercial places, resulting in more impervious surfaces in urban areas that create uncontrolled water runoff, thus exposing city people to increased flooding occurrences. As an example, while there is a priority to erect skyscrapers and buildings in the name of economic development, this is actually replacing and/or threatening aquatic ecosystems such as lakes and wetland areas. The end result is a serious compromise of available water resources.

Therefore, large city areas do not have the capacity of absorption, purification and filtration of rainwater leading to flooding disasters or their re-occurrence (Dong et al., 2018; Li et al., 2018; Wang et al., 2018). Unsuitable urban planning strategies including poor and insufficient 
drainage systems and urban development on the floodplains have created serious problems for the environment and simply increased the threat of urban flooding ( $\mathrm{Li}$ et al., 2017; Li et al., 2016; Liu, 2016; Liu et al., 2017). For instance, traditional urban drainage systems are inconsistent with urbanization and climate change, their facilities are outdated and their design standards for stormwater management have failed to adapt to urban population growth (Jiang et al., 2018; Nkwunonwo et al., 2016). The construction and development of buildings and industrial areas on the floodplains on one hand exacerbates the risk of urban flooding (Nkwunonwo et al., 2016). It is therefore necessary to construct an effective and conventional rainwater management system so that it is consistent with urban expansion and climate extreme events as well. Launched in 2015, many Sponge City projects have been invested with the capacity to absorb and re-use at least $70 \%$ of stormwater for soaking up floodwater.

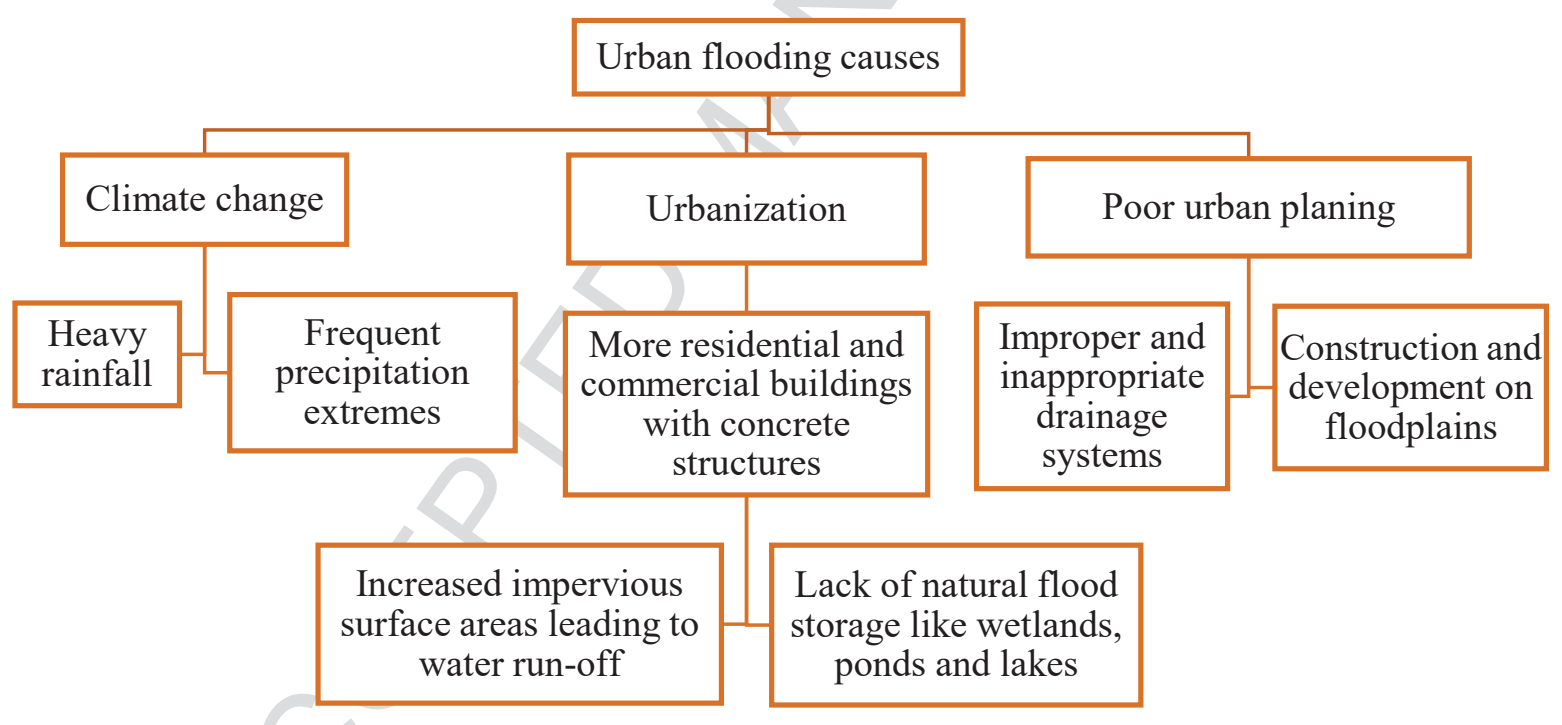

Figure 1. The main causes of urban flooding

(Modified from Nkwunonwo et al., 2016.)

\subsection{Evolution of adoption}

Sponge City evolved from traditional urban water management models. Urban stormwater management has existed in human societies as early as 3000 BC (Burian and Edwards, 2002) where the aim was to avoid flooding and collect rainwater. Urban drainage development has 
evolved through four main periods of human history, these being: the ancient world; the Roman Empire; the post-Roman era to the 19th century; and lastly, from the 19th century to now (see Table 1). According to David (2014), the history of water technologies can be divided into 4 periods (designated Water 1.0 to 4.0) from $2500 \mathrm{BC}$ to the present day. In Water 1.0, the growth of Rome's population during the Roman Empire period led to increased demand for water; therefore, Roman engineers constructed an initial water system for importing and its distribution to households and public spaces through pipe networks and then the used water released back into the environment. Water $\mathbf{2 . 0}$ began when the United States' economy grew but the burgeoning industries contaminated rivers through polluted wastewater. To deal with this situation, American bacteriologists created an innovative wastewater system known as biofilm to purify contaminated water so that it was fit for drinking purposes. During Water 3.0, the development of sewage treatment was the focus by building holding ponds to consolidate water and regularize the speed of sewage flow through filters, which controlled microbes to treat toxic waste before being discharged into rivers. The final stage, Water 4.0, is one where the next generation of drainage system solves all problems of the previous three water systems by replacing outdated urban water infrastructure and making the community more aware about how to manage water resources (Sedlak, 2014).

Table 1. A comparison of different urban drainage systems from $3000 \mathrm{BC}$ to the present

\begin{tabular}{lllll}
\hline No. Period & Objective & Achievement & Limitations \\
\hline 1 & Ancient & Rainwater & Numerous successful and & Lack of \\
& collection; & uneconomical & sewer & optimization and \\
& flooding & systems parallel with social & numerical standards \\
& mitigation; & planning & before construction \\
& and conveying & & (Herbert, 1961) \\
& & &
\end{tabular}




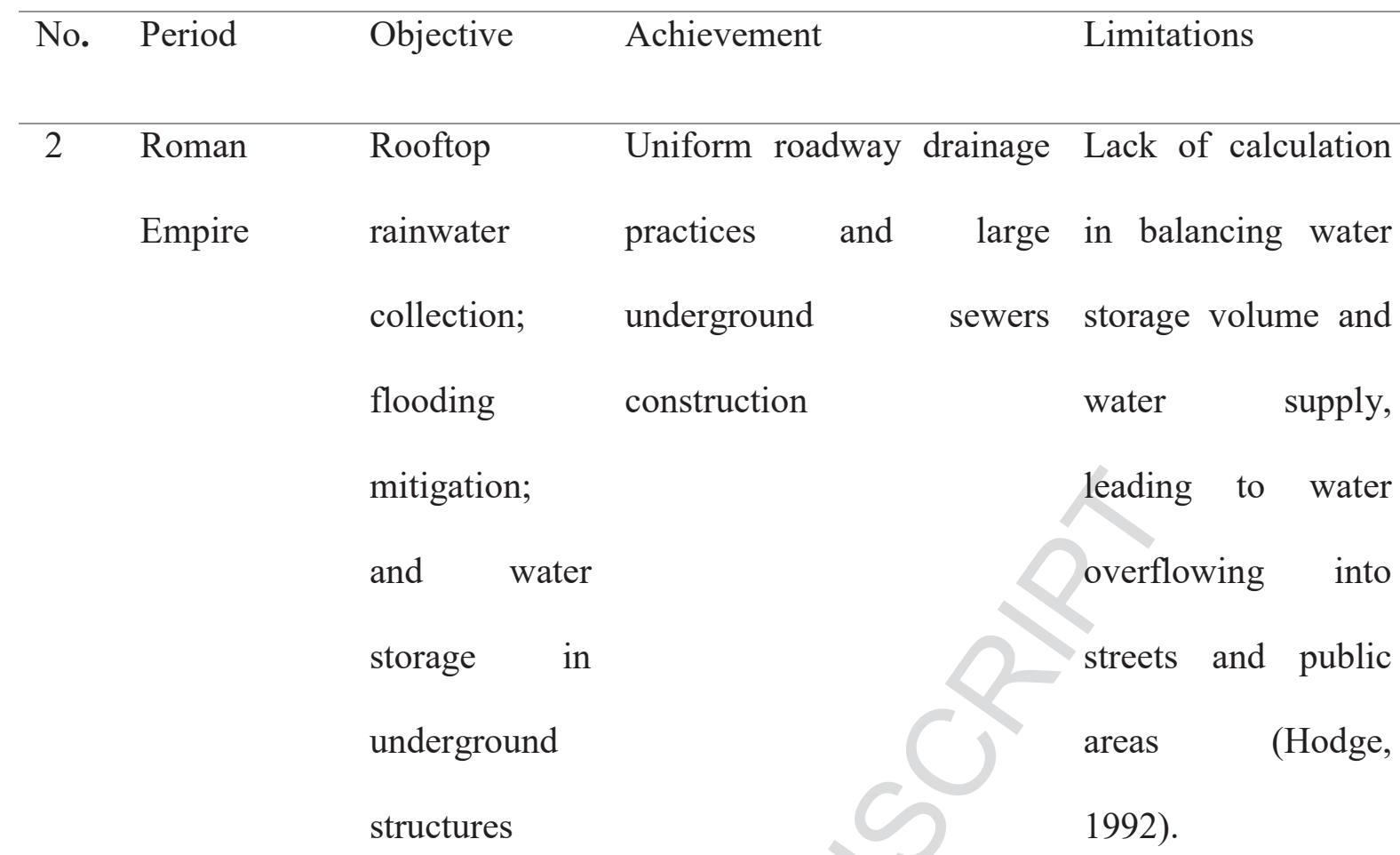

3 Post-Roman Flooding Stone roadways with Exposing many

era to the mitigation and surface and subsurface urban drainage

1800s wastewater drainage systems problems due to the

removal constructed with a crown in insufficient

the centre and gutters along maintenance of

the sides; and sewers made sewers and

of wood subsequent spread

of diseases.

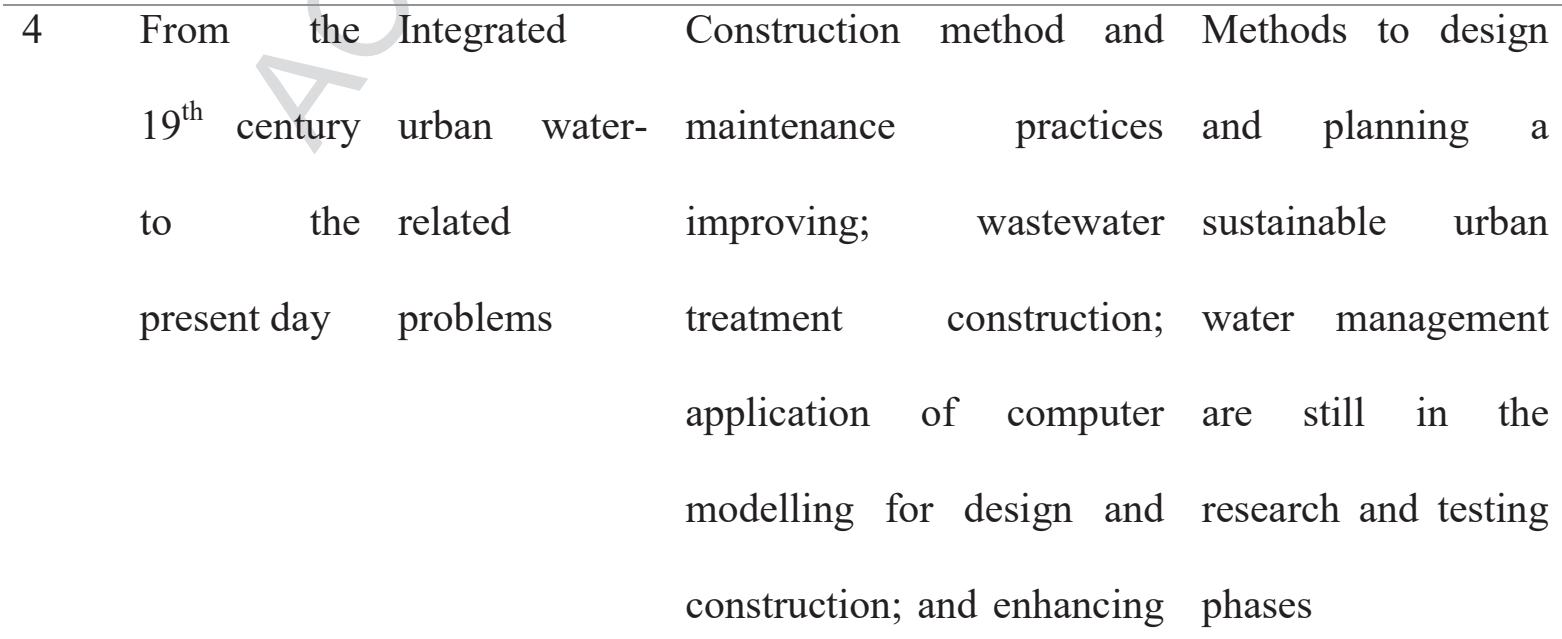


No. Period Objective Achievement Limitations

environmental awareness

Drainage systems have evolved over many centuries during trial-and-error modifications and after their implementation with increasing sophistication and multi-purpose possibilities. Whilst initially the primary objective of urban rainwater management was flood mitigation in combination with rainwater collection for private purposes, from the $19^{\text {th }}$ century until now, this goal has expanded to integrate other aspects. They include water resources management, biodiversity and recreational and community purposes. In the $20^{\text {th }}$ century, industrialized countries in the West developed policies and strategies to address urban water-related issues due to their massive urban and industrial expansion. Strategies included: best management practices (BMPs); low impact development (LID) in the United States in the 1940s (Ice, 2004); water sensitive urban design (WSUD) in 1990s Australia (Wang et al., 2018); and in the 2000s, sustainable urban drainage systems (SUDS) in the United Kingdom. The abovementioned stage Water 4.0 focuses on water protection and improving local people's awareness of water usage.

Various Sponge City models have been conceived under BMPs-LID in the U.S. for rainwater collection and improving the quality of water. BMPs-LID were divided into two broad groups: structural and non-structural. Structural BMPs-LID included ponds, wetlands and green rooftops (Scholz, 2006) that were built as multi-functional concepts for flooding mitigation, water quality enhancement, creating green spaces for recreation, and supporting ecosystems and wildlife. Urban water management in Australia experienced five different stages including water supply city, sewered city, drained city, waterways city and water cycle city before implementing water sensitive cities under water sensitive urban design (WSUD) with the objective of climate change resilience and ecological integrity (Brown et al., 2009). 
The purpose of these concepts is to introduce integrated urban water management so that development is sustainable. Doing so will ensure the optimal management of water supply, water treatment and limiting flooding from storm events.

These initiatives involved the design of drainage systems that would be constructed according to the demands of sustainable development by considering all the issues including quantity, quality and amenity in stormwater management. Hence, these strategic designs have resulted in improving community values, biodiversity, educational and recreational functions and multiple purposes of space (Developer, 2007). These strategies differ from traditional approaches of urban rainwater management because the latter did not balance amenity aspects or pay much attention to issues of quality or quantity.

Traditional approach

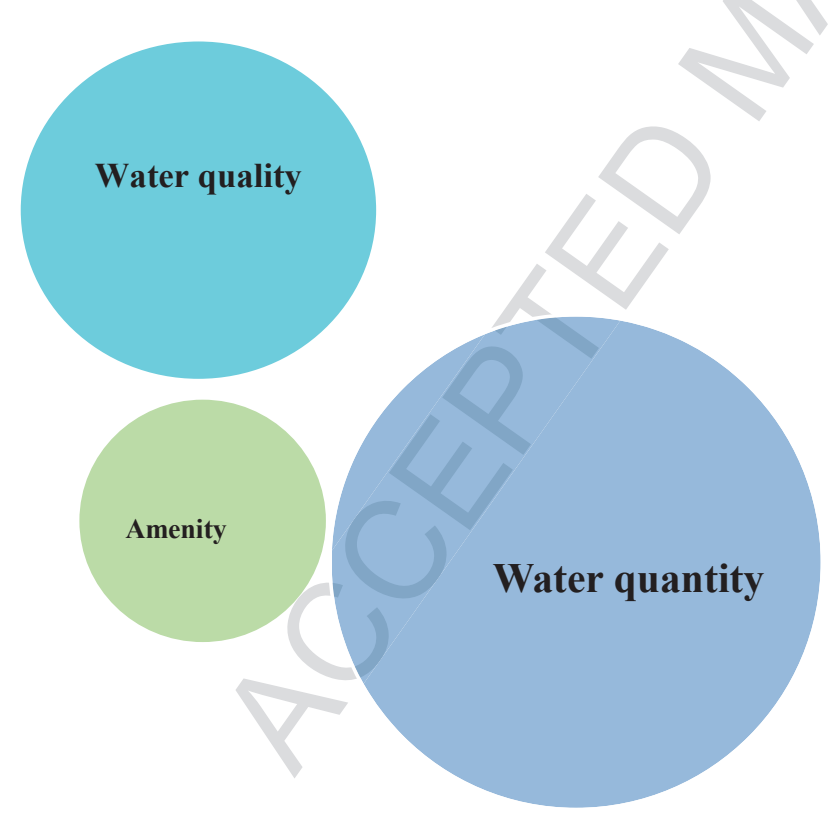

Sustainable approach

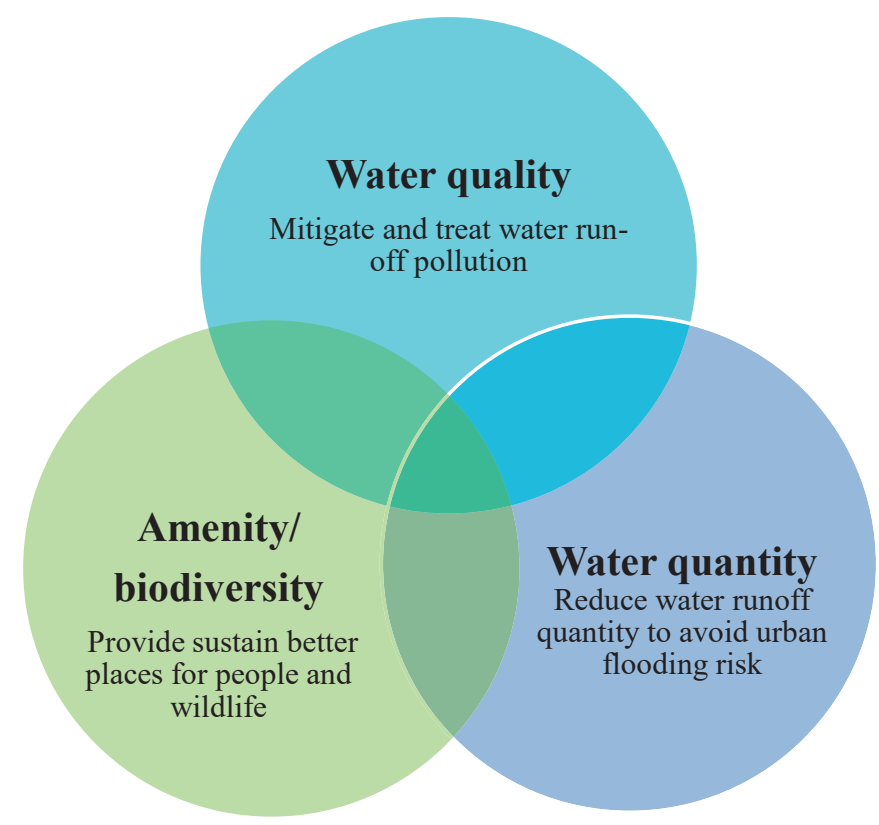

Figure 2. Differences between traditional and sustainable approaches of urban drainage systems

(Modified from Charlesworth, 2010.)

Although the structural BMPs-LID, sustainable urban drainage systems (SUDS), water sensitive urban design (WSUD), and Water 4.0 have been applied to solve different water 
problems in developed countries, it is still very much a new concept in developing countries. It is vital to utilize the most appropriate urban water management practices that are suitable for developing countries. SUDS and WSUD focus on natural hydrological protection and management of stormwater. In addition, David's (2014) Water 4.0 concept mainly considers water supply distribution and its value to society in the U.S. This type of strategy finds it difficult to address the complicated urban water-related problems that occur in developing countries like China (Ren et al., 2017). Urban water management problems first raised the concerns of scientists and authorities in China in the 1990s (Wang et al., 2018). Since then they have concentrated on how to design drainage systems as a sustainable water supply for the cities. From 2000 to 2007, the objective of urban water management in China was to recycle stormwater and treat wastewater. In the following 5 years, urban water strategies in China increasingly focused on optimizing urban water drainage system for city water distribution and sewage purification.

However, some water-related issues associated with flooding disasters and water shortages still exist in large areas of China. This started to occur when the Chinese government launched the "Open Door Policy" in the late 1970s and the country witnessed rapid urbanization and socio-economic growth. For example, the population quadrupled from 1978 to 2015 (Chan et al., 2018). This mean that land used for green spaces, wetlands, forestry and agriculture was converted on a massive scale to urbanized zones where commercial, residential and industrial development predominated. This drastic loss in natural environment capital resulted in rainfall infiltration and absorption reduction, and less recharge of groundwater due to a lower retention capacity of rainwater in urban regions in China, which results in water shortage in these regions (Arshad et al., 2014; Qin et al., 2013). Consequently, many cities in China have experienced flood disasters because of the inappropriate urban drainage system and the phenomenon of unpredictable weather. For this reason in 2014, the Sponge City concept became a reality in China to help develop sustainable cities (Jia et al., 
2017; Wang et al., 2018) and provide an integrated urban water management solution. Figure

3 illustrates different urban water strategies worldwide and the implementation of urban water management strategies in China.

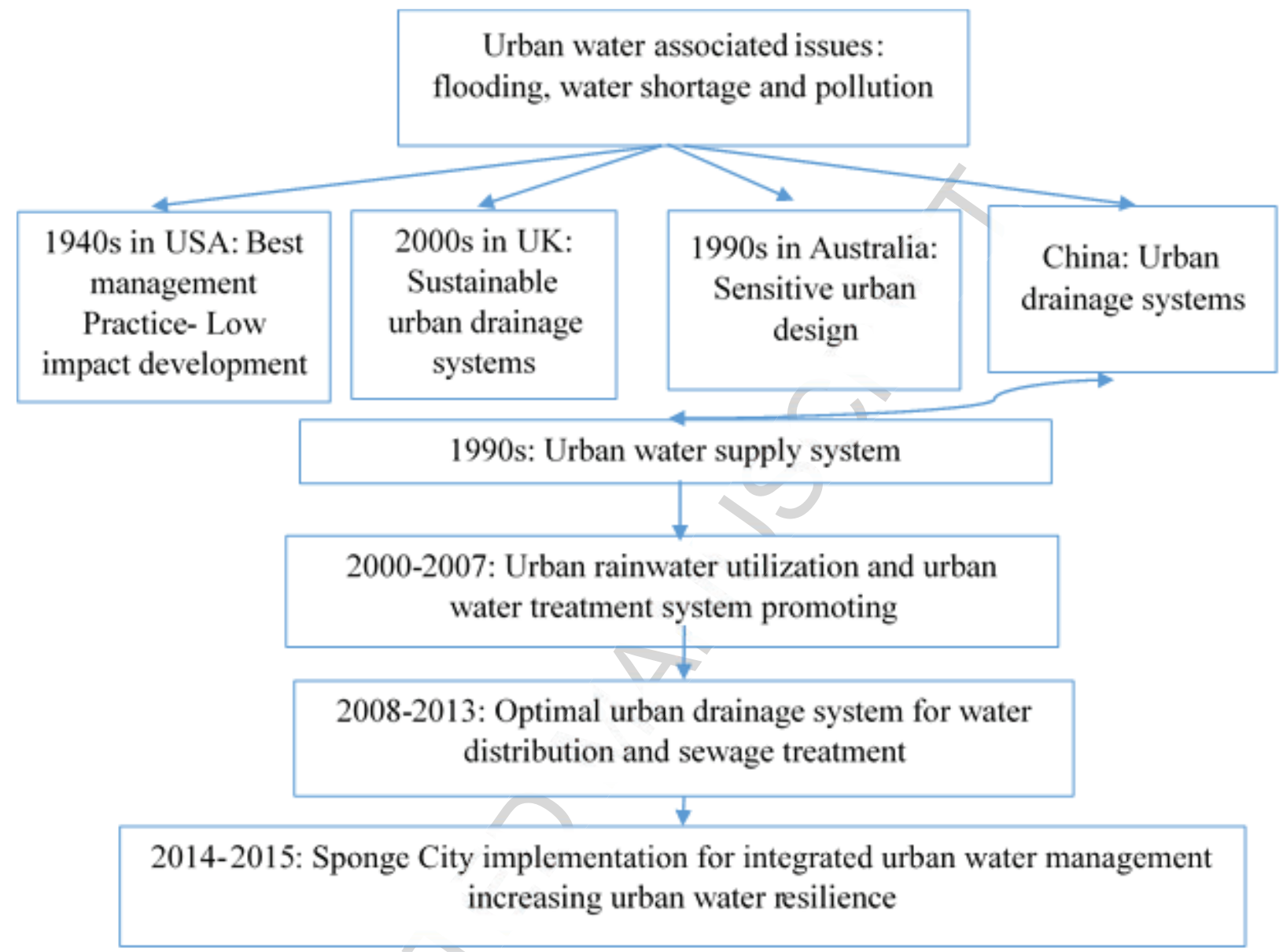

Figure 3. Different urban water strategies of the $20^{\text {th }}$ century

A Sponge City is designed and implemented according to LID strategies that require the designer and builder having to mitigate the impact of construction on the environment including water, soil, vegetation, and biodiversity. Thus, respecting nature is the core value of LID strategies. Low impact development strategies aim to build sustainable drainage systems, better urban water cycle design and rainwater source controls. Technical methods in LID assist water infiltrating, filtering, evaporating, harvesting and surface runoff reduction while mitigating pollution. Therefore, the purpose of the Sponge City is to absorb, store, treat stormwater and provide stored water for the public when needed through green infrastructure 
applications, for example, green roof, raingarden or bio-detention (Wu, 2015). These measures help to balance the urban water circulation system and create a high-quality living environment for both people and wildlife.

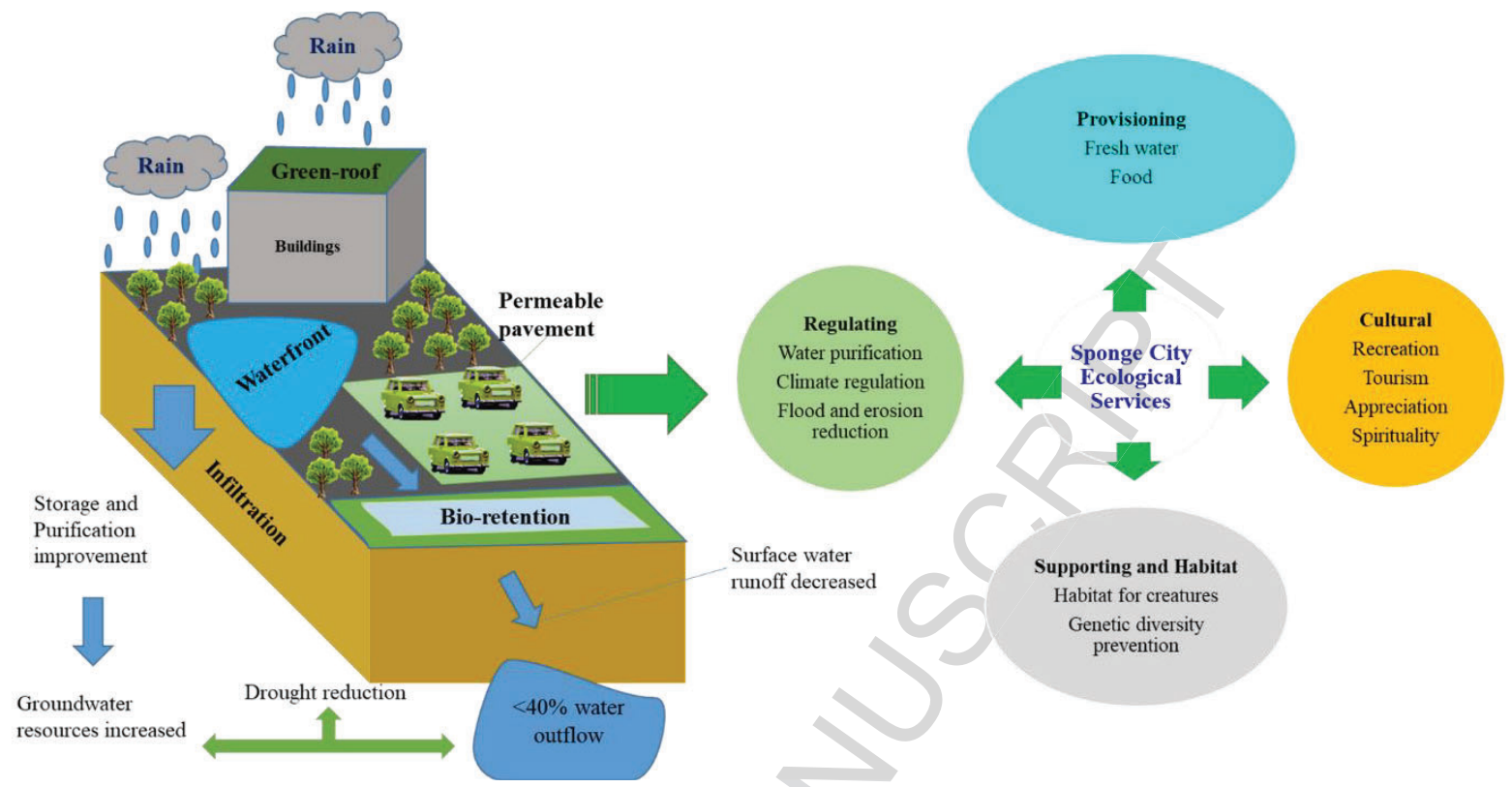

Figure 4. Schematic design of the Sponge City and Sponge City Ecological Services

There are many Sponge City objectives (see Figure 4). Firstly, it aims to control urban flooding disasters (Jia et al., 2017; Wang et al., 2018). In terms of climate change and urbanization, many cities in China face extreme urban flooding hazards. To solve this problem, Sponge City has developed alternative infrastructures, for instance green roofs, bioretention and permeable pavements to increase water absorption and reduce water runoff. As a result, urban flooding can be mitigated yet it has to be recognized that an increase in wastewater due to population growth and industrialization results in serious water pollution in Chinese cities, affecting people's health and well-being. Secondly, the purpose of the Sponge City is to enhance water quality in urban areas by self-purification systems and ecological waterfronts. The next goal is to recycle stormwater for urban water supply. Here the rainwater is transformed into a resource, with the purpose of tackling water shortages in the cities, which is especially critical during times of drought. 
From 2000 to 2007, the Chinese government implemented green infrastructure for stormwater utilization, but this system's efficiency in utilizing rainwater was initially very poor. The reason was the lack of ideal factors including green technologies and materials (Liu et al., 2013; Shi et al., 2015). This meant that the ideal of the Sponge City improving green infrastructures so that $70 \%$ of stormwater could be consumed or utilized was in fact undermined. The final aim of Sponge City is to create a pleasant city microclimate. Reducing the city's heat through increasing the green spaces with green rooftops, lakes and wetland areas is strongly desired. In summary, it can be stated that Sponge City enhances a city's ecology in four key ways (Gómez-Baggethun et al., 2013) (Figure 4): provisioning of fresh water and food; regulating the proper cultural use of recreation spaces; and building wildlife habitat services. Sponge City combats complex urban water-related issues and brings many benefits for city development compared to the older urban water management systems (see Table 2).

Table 2. Fragmented engineering measures in older urban water management systems compared to the Sponge City approach

\begin{tabular}{|c|c|c|c|}
\hline No. & Goals & Older urban water & Sponge City \\
\hline 1 & $\begin{array}{l}\text { Flooding disaster } \\
\text { reduction }\end{array}$ & $\begin{array}{l}\text { Based on urban river and } \\
\text { hard stormwater systems }\end{array}$ & $\begin{array}{l}\text { Building natural hydrological } \\
\text { cycle protection and urban } \\
\text { resilience }\end{array}$ \\
\hline 2 & Water supply & $\begin{array}{l}\text { From ground/surface water } \\
\text { like rivers and water supply } \\
\text { plants }\end{array}$ & $\begin{array}{l}\text { Stormwater reused by non- } \\
\text { potable water supply }\end{array}$ \\
\hline 3 & $\begin{array}{l}\text { Water quality } \\
\text { improvement }\end{array}$ & $\begin{array}{l}\text { Depending on centralized } \\
\text { sewage treatment plant }\end{array}$ & $\begin{array}{l}\text { Creating decentralized system } \\
\text { for in-situ reuse of } \\
\text { wastewater. }\end{array}$ \\
\hline 4 & Water Purification & No & Yes \\
\hline
\end{tabular}




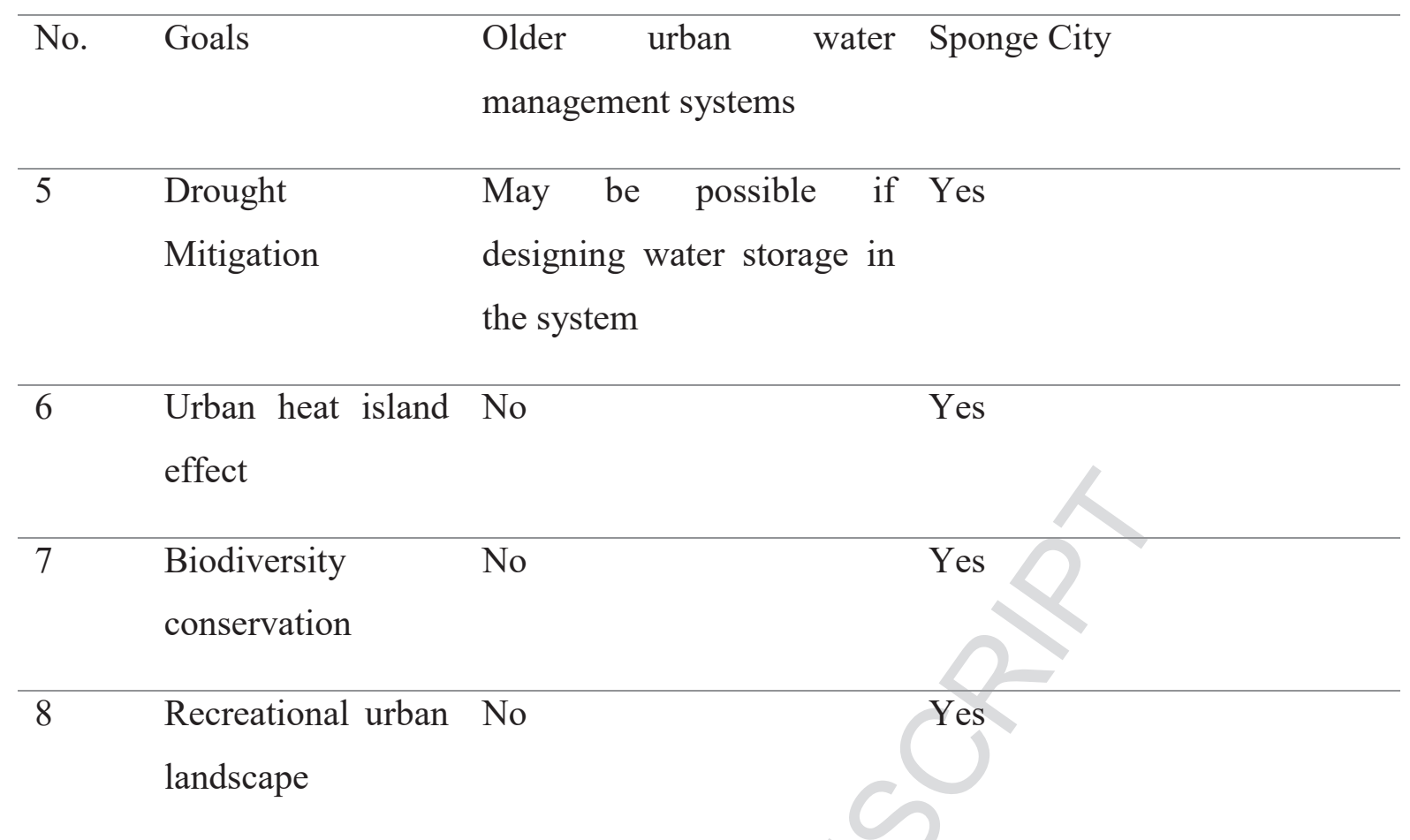

Utilizing both green and grey infrastructure can enhance urban resilience. Being greener would provide higher adaptability and resistibility to addressing unpredictable climate forecasts in the future, whilst grey development contributes to unsustainable urban drainage system practices. Up until now, building grey infrastructure is still the main development method in China to cope with the influx of people who have to be housed quickly. Because the two kinds of infrastructure (grey and green) provide different benefits in terms of outcomes of resilience and improvements, a good strategy is to integrate green and grey infrastructures into one hybrid control system. Doing so will bring about more advantages and reduce problems whilst improving the resilience of existing urban drainage systems (Dong et al., 2017).

\section{Sponge City initiative}

\subsection{Principle concepts}

There are four main principle concepts involved in the Sponge City. The first aim is to make the surface of the city better able to absorb and store rainwater in order to supply water and to mitigate the water runoff, given that the latter can lead to floods. The second principle is 
about water ecology management via water self-purification systems and the provision of ecologically friendly waterfront design. The third is concerned with the application of green infrastructure to purify, restore, adjust and reuse stormwater, which helps the cities avoid water and soil pollution. This will curtail the urban 'heat island' effect and support sustainable urbanization. Fourthly, using permeable pavements in urban road construction will benefit a Sponge City.

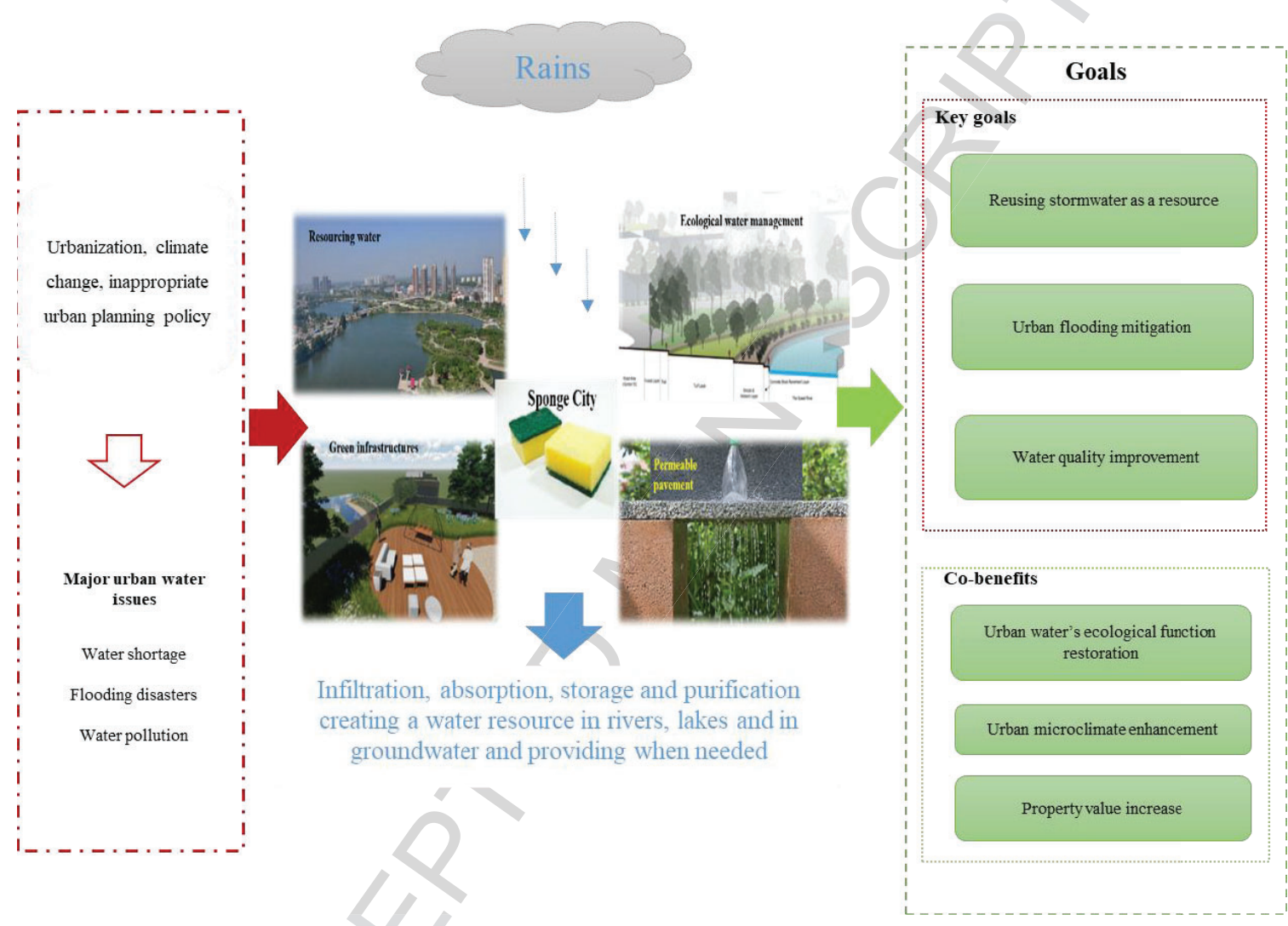

Figure 5. Urban water issues, Sponge City's principle concepts and goals

Sponge City implementation can be divided into macro-scale and micro-scale scenarios. In the micro-scale context, the main focus is on implementing designs for site level including rain gardens, stormwater-bio-retention and constructed wetlands. From maximizing the effective of micro-scale Sponge City in site level and localized level, Sponge City is scaled up into catchment level in order to enhance hydrological and bio-ecological benefits (Zhang and Chui, 2019). Regarding the macro-scale, stormwater infrastructure systems are integrated with natural hydrology systems to protect riparian corridors including grass, trees, shrubs and 
the buffer areas of these corridors. A novel model that incorporates the available spatial data (social-economic, land use, climate, green infrastructure practices and hydrological condition information) plays a vital role in upscaling of Sponge City technologies from plots and localized areas to catchments (Golden and Hoghooghi, 2018; Zhang and Chui, 2019). Table 3 below summarizes the micro-scale and macro-scale contexts of the Sponge City approach in terms of hydrological, water equality and bio-ecological benefits. It should be noted here that the micro-scale benefits drive the macro-scale benefits. Bio-ecological and water quality benefits are created by hydrological benefits by enhancing water infiltration and water flow recharge (Zhang and Chui, 2019). Successful implementation of a catchment-scale Sponge City can be achieved by maximizing green infrastructure practices.

Table 3. A comparison of Sponge City advantages in micro scale and macro-scale (Adapted from Zhang and Chui, 2019)

\begin{tabular}{|c|c|c|c|}
\hline & Hydrological benefits & $\begin{array}{l}\text { Water quality } \\
\text { benefit }\end{array}$ & $\begin{array}{l}\text { Bio-ecological } \\
\text { benefits }\end{array}$ \\
\hline Micro-scale & $\begin{array}{l}\text { Water infiltration and } \\
\text { recharge improvement } \\
\text { Decrease of water surface } \\
\text { runoff peak and volume } \\
\text { Increase in evapotranspiration }\end{array}$ & $\begin{array}{l}\text { Water quality } \\
\text { control }\end{array}$ & $\begin{array}{l}\text { Soil environment and } \\
\text { vegetation growth } \\
\text { improvement }\end{array}$ \\
\hline \multirow[t]{3}{*}{ Macro-scale } & $\begin{array}{l}\text { Base flow and stream flow } \\
\text { recharge improvement }\end{array}$ & $\begin{array}{l}\text { Water quality } \\
\text { enhancement }\end{array}$ & $\begin{array}{l}\text { Urban-environment } \\
\text { enhancement }\end{array}$ \\
\hline & $\begin{array}{l}\text { Enhancement of hydrologic } \\
\text { connectivity }\end{array}$ & & $\begin{array}{l}\text { Biodiversity } \\
\text { conservation }\end{array}$ \\
\hline & Protection against flooding & & Erosion reduction \\
\hline
\end{tabular}




\subsubsection{Resourcing rainwater}

The rapid increases in population, urbanization and industrialization and excessive water use for agriculture pose real and long-lasting threats to existing water resources. Therefore, an alternative water resource is required to combat the lack of water resources, given that sustainable water resources management plays a vital role in socio-economic development. Stormwater harvesting is one of the oldest methods known for addressing water shortage (Campisano et al., 2017). Rainwater harvesting (RWH) includes the storage of rainwater from rooftops and other building surfaces for domestic purposes such as irrigation, household laundry and cleaning. Many technologies were developed to construct RWH systems, for example, tank systems for rainwater recycling in Japan in the early 1980 s and green roof infrastructure in Germany in the 1960s (Campisano et al., 2017). Rainwater harvesting systems have been introduced successfully in Australia, the United States and European countries on a small-scale. Recently, such practices are being increasingly implemented in developing countries. Rainwater harvesting is a feasible solution not only to alleviate an increased water demand in many countries, but also to mitigate water runoff (Campisano et al., 2017; Christian Amos et al., 2016).

The existing RWH initially focused on the restoring and recycling of stormwater without paying attention to the many benefits of RWH. RWH in an integral part of the LID, SuDS and Sponge City concepts, and it aims to ameliorate the peaks, frequency and volumes of urban water runoff (Christian Amos et al., 2016). In order to ensure a Sponge City successfully resources rainwater, it is necessary to understand the area's hydrological characteristics including water surface runoff, flow time, discharge, speed, size and peak time to better connect between natural water networks and urban drainage systems to control urban flooding. In this way, the water storage capacity of urban infrastructure can be enhanced. As well, a wetland ecosystem design including natural and artificial designs for RWH is important for Sponge City rainwater resourcing construction, as it will improve climate 
regulation, flood prevention and water purification. The community can enjoy the 'saved' landscape for entertainment and leisure activities.

\subsubsection{Ecological water management}

Rapid urbanization and industrialization have threatened the water quality in many areas. The Sponge City concept ensures the water environment is restored ecologically through a selfpurification system and waterfront design, with the creation of healthy water landscapes for people and wildlife. The water self-purification process is very complicated in that it includes physical, chemical and biological processes. Normally, the biological purification process is considered an environmentally friendly method. There are four factors, which significantly influence water self-purification. The first factor is the hydrodynamic force, which adds to a mixture of pollutants, their movement and the water dissolved oxygen content. Soil is the second factor and it serves to remove pollutants through absorption, sedimentation and filtration. The third one is plants that can remove heavy metal pollutants, nitrogen and phosphorus. Fourth and finally, microorganisms can help contaminant degradation. Another form of ecological water management is ecological waterfront design. Waterfront design aims to integrate cities and a water system in order to develop macro- and micro-urban environments. In the construction of a Sponge City, both natural and artificial ecological waterfronts can protect against riverbanks' erosion and consolidate the water self-purification system (Wu, 2015).

\subsubsection{Green infrastructure}

Green infrastructure has emerged as the solution to protect the environment and make urban environments sustainable. The implementation of Sponge City can be involved in a wide spectrum of green infrastructures with nature-based solutions such as detention basins, infiltration systems, filter drains, filter steeps, swales and wetlands. There are two main types 
of green infrastructure in Sponge City implementation: green roofs and bio-retention. These kinds of infrastructure are described in more detail below:

\section{$>$ Green roofs}

Green roofs are also known as living roof or rooftop garden (Mentens et al., 2006; Sailor, 2008; Shafique et al., 2018; Stovin, 2010). Green roofs are constructed to be covered by vegetation and/or plants. The green roofs concept has been documented in LID strategies and SUDS techniques. Green roofs promote vegetation planting on the tops of buildings. They serve to: reduce stormwater runoff; mitigate the urban heat island effect; reduce energy consumption; enhance air and water quality; improve wildlife habitat and plant life; and boost recreational activities through green areas (Besir and Cuce, 2018; Brudermann and Sangkakool, 2017; Chen et al., 2018; Coma et al., 2018; Mentens et al., 2006; Sailor, 2008; Shafique et al., 2018). The application of green roofs started many years ago but the modern green roof system started initially in Germany during the early 1960s with the aim of reducing energy consumption for buildings. Germany is considered a leader in green roof technology because its system is well developed, designed and implemented on a large-scale (Zhang et al., 2011). Figure 6 presents the history of green roofs worldwide. They were first introduced into China during the 1980 s and in the U.S. in the 1990s. The Environmental Protection Agency of the United States published documents (2009) on how to construct green roofs and what the advantages benefits are. Some years later, more studies about the design, implementation and maintenance of green roofs were conducted in the U.S. (Jim, 2017; Shafique et al., 2018). Currently, green roofs are being built in many countries thanks to successful implementation of green roofs in Germany, the United States and European countries. 


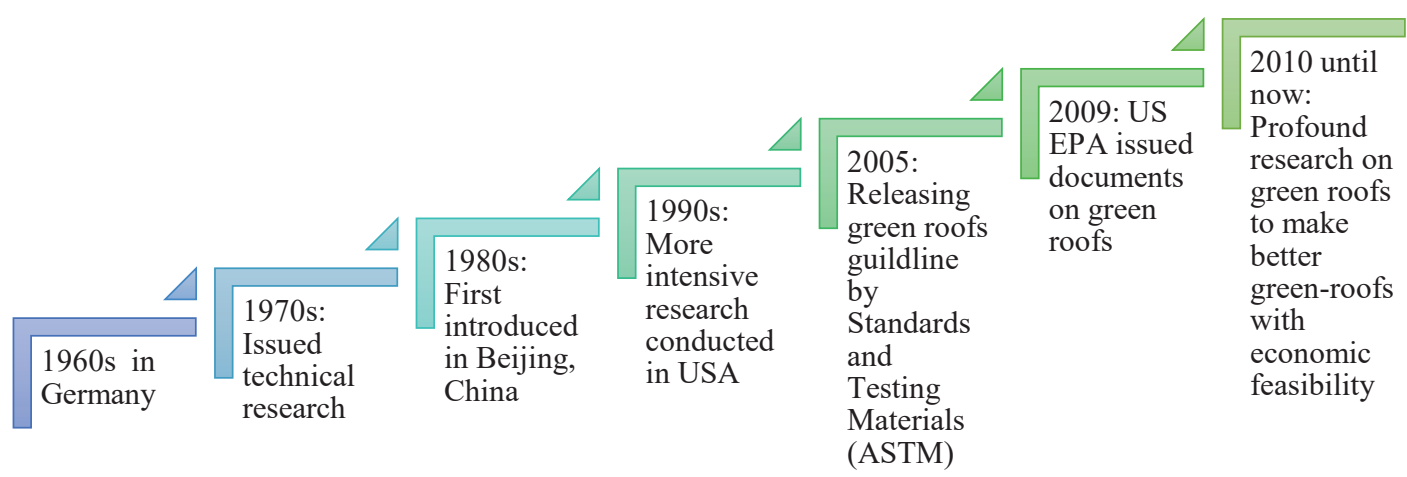

Figure 6. History of the development of green roofs around the world

Green roofs consist of five main components, these being waterproof membrane, a layer of drainage system, a filter membrane, soil and plants (Zhang et al., 2018b). Each layer needs to be selected based on the physical and climatic conditions. There are four types of green roofs: intensive; semi-intensive; multi-course extensive; and single-course extensive. Their respective substrate thicknesses are $>12$ inches, 6-12 inches, 4-6 inches and 3-4 inches (Molineux et al., 2017). Of these the single and multi-course extensive green roofs are most popular because they weigh and cost less, are easy to maintain and do not require irrigation. Green roofs are advantageous as they support natural hydrology and the environment. Although this research aims for best practice in encouraging countries to adopt the most suitable green roof systems, further $R \& D$ is required. This is particularly the case in developing countries given their diverse climates and geographical conditions in comparison to developed countries, for example, in Germany or the United State (Besir and Cuce, 2018).

\section{Bio-retention}

Bio-retention systems are also known as bio-filters or raingardens (Davis et al., 2009; Fujita, 1997; Laurenson et al., 2013; Mangangka et al., 2015; Trowsdale and Simcock, 2011). Normally, a bio-retention system consists of five overarching components, which are drainage layer, transition layer, submerged zone, filter media and detention layer (see Figure 7). Each layer in the bio-retention system is constructed according a specific area's characteristics. These help filter polluted stormwater and remove contaminants via biological processes using 
active plants and sandy loam layers. Bio-retention systems are considered to be feasible solutions in sustainable rainwater management practices (Muthanna et al., 2007). They are designed to manage stormwater peak flow, runoff volume reduction, groundwater recharge enhancement and stream base flow maintenance (Davis et al., 2009; Randelovic et al., 2016; Rycewicz-Borecki et al., 2017; Wang et al., 2017a).

Bio-retention systems can potentially regulate water quality and control non-point source pollution (Jiang et al., 2017a). These systems, as small sponges for cities, have been a popular method to mitigate urban flood disaster (Jiang et al., 2017a). In researching the urban context, previous studies paid more attention to the performance of bio-retention in hydrological systems, but did not focus on the role of these systems in terms of urban stormwater management and climate change. Published studies on effective improvement of bio-retention in terms of climate change and urbanization are very few (Wang et al., 2016). It is therefore critical to conduct an extensive research for the assessment of bio-retention's function and life cycle maintenance. More experiments need to be done to evaluate the biological and hydrological performance of bio-retention systems (Liu et al., 2014). Also, the appropriate computational model to forecast bio-retention's efficiency before implementing is needed. 


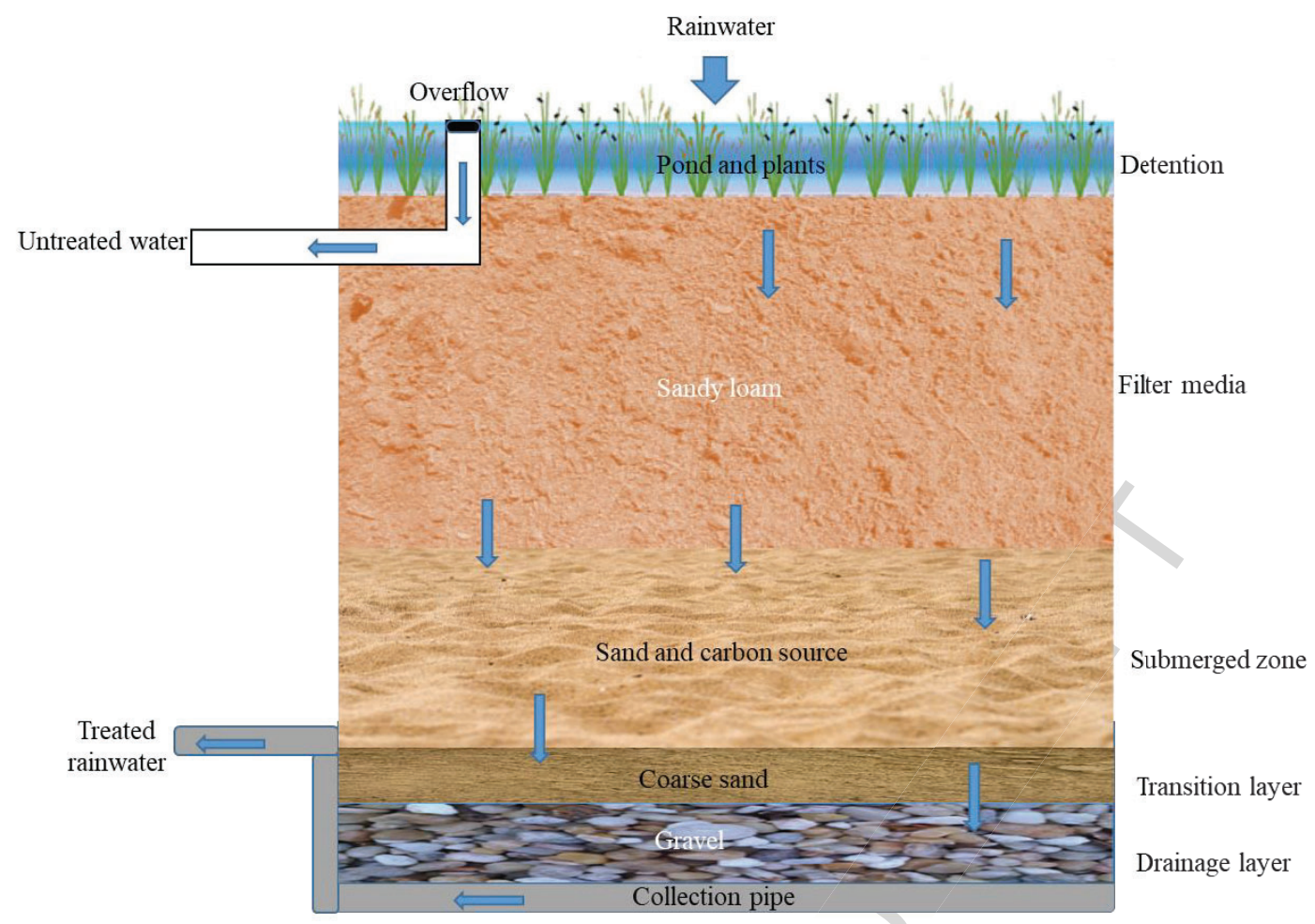

Figure 7. Bio-retention design

\subsubsection{Urban permeable pavement}

Permeable pavement is a Sponge City technology utilizing permeable materials to build ground pavement, the aim being to improve rainwater infiltration, and purification of groundwater for urban supply, reducing water runoff, cooling, humidification, noise reduction, and environmental and ecological soil restoration (Hu et al., 2018; Liu et al., 2018; Scholz and Uzomah, 2013; Yu et al., 2017). Urban pavement includes roads, squares, parking lots, and urban site walkways (Kamali et al., 2017). Each type of urban pavement is designed differently depending on traffic quantity and road loads. There are four main types of permeable pavements: grass pavement (GP), permeable asphalts (PA), permeable concretes (PC), and permeable interlocking concrete pavers (PICP) (Woods Ballard et al., 1015). PC performs better than PA and PICP if without considering the impact of clogging by particle deposition concentrations on the surface of permeable pavement ( $\mathrm{Hu}$ et al., 2018). These permeable pavements have been studied and adopted in many parts of the world to mitigate 
flood disasters using urban water management practices, such as low impact development and best management practices (Brunetti et al., 2016; Hu et al., 2018).

Permeable pavement parking lots may significantly benefit eco-systems because they have the potential for rapid infiltration of stormwater, which will reduce a high level of water runoff (Kumar et al., 2016). Some studies found that the performance of permeabele pavements in terms of flooding reduction is even better and more effective than other Sponge City technologies, including greenroofs or rainwater resourcing (Chandana et al., 2010; Hu et al., 2018). For example, the construction of permeable pavements reduced total water runoff in Tianjin University campus, China, by nearly 35.6\% (Huang et al., 2014). However, the construction of urban permeable pavements should be suit the local conditions and need to take consideration the clogging problem and life cycle of permeable pavements. In highly polluted regions and unfavorable soil permeabiltiy, this technique is not suitable (Yu et al., 2017).

\subsection{Overview of current implementation}

Hard engineering-based management measures are still prevalent particularly in the developing urban environments where flooding disasters and water-related issues must be confronted. The Chinese government adopted the Sponge City Program (SCP) in 2014, to deliver nature-based solutions for urban water-related problems. The overarching objectives were to absorb and reuse $70 \%$ of stormwater in urban areas by developing or improving permeable surface systems to infiltrate, store and purify rainwater for reuse, and replace the impervious infrastructure systems (see Figure 8). The idea behind Sponge City is to construct

urban areas that are less likely to impact on the natural environment, and here its implementation will differ depending on urban areas' geographical context, climate conditions and their development strategy and plan (Li et al., 2018). Since 2016, the Sponge City objectives have comprised sustainable goals for water urban development in ecosystems 
restoration, degraded water bodies enhancement, urban heat island effects mitigation and smart urban water cycle construction (Li et al., 2017; Li et al., 2018; Li et al.; Liu et al., 2017).

Impervious surfaces

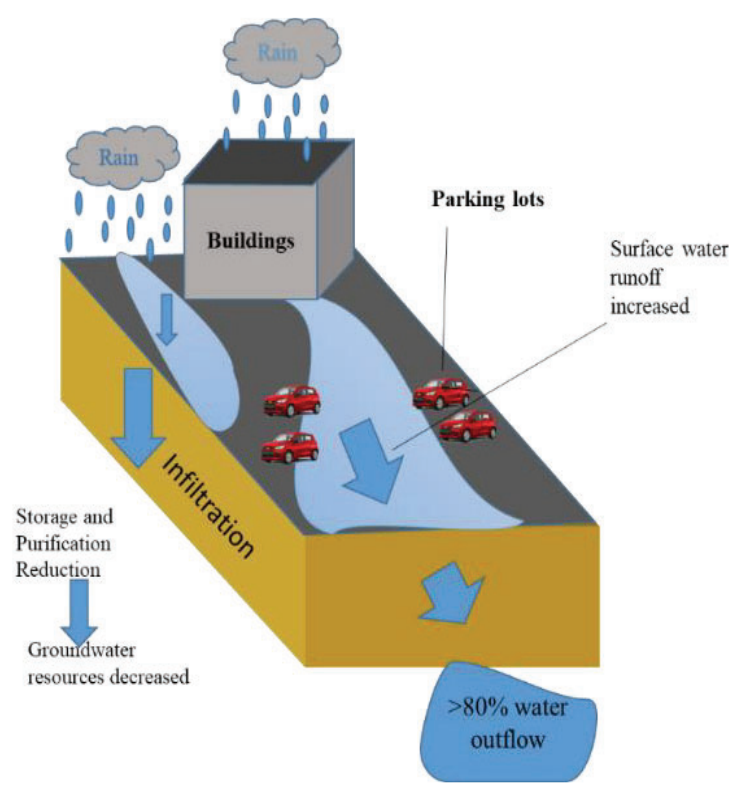

Pervious surfaces

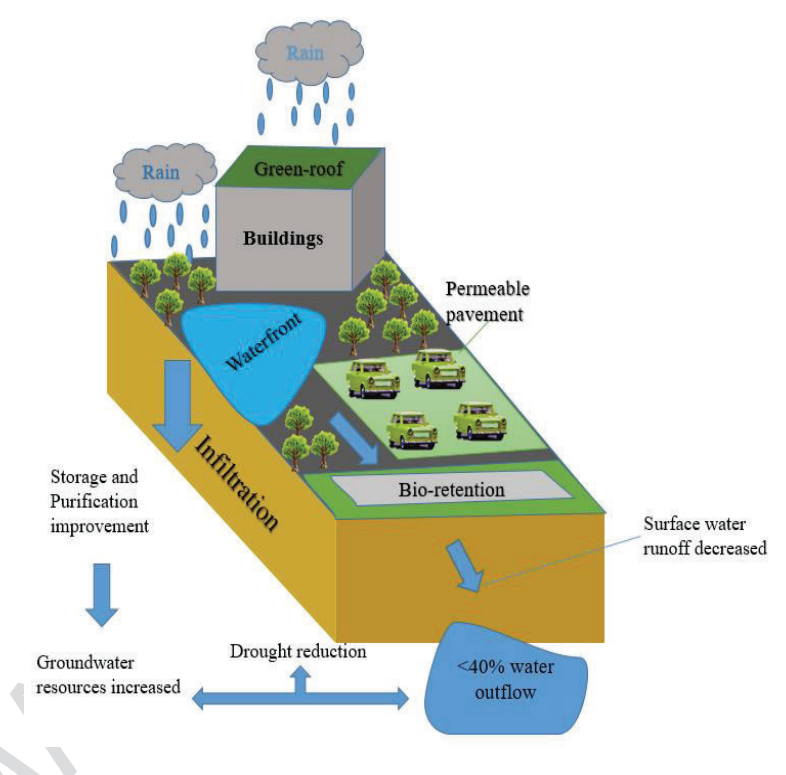

Figure 8. Difference between impervious surfaces and pervious surfaces

The implementation of Sponge Cities now follows a sustainable or greener approach specifically addressing urban water-related problems. Building diverse sponge infrastructures of green roofs, parks, and waterfront areas is promoted. All cities in China are expected to take part in the Sponge City program because the attraction of initial investment from their central government to assist Sponge City construction. Actually, the Chinese central government invested initially approximately US\$50-100 million for SCP each pilot city (Association, 2017). Yet this level of funding may still be insufficient for the overall project. In the near future, China's government does expect private funds and public-private sector partnerships to drive the investment in building Sponge City infrastructure. The expectation is that $50 \%$ funding of total investment will originate from the private sector, local governments will contribute $40 \%$, and the central government will contribute 10\% (see Figure 9a) (Liang, 2018). However, regarding public perspective (Figure 9b), $72.63 \%$ of respondents believed 
that the primary financial source for SCP should come from government's subsidy (Wang et al., 2017b). From both perspectives, the commitment of China's local municipalities and public-private partnerships (PPPs) will be significant to Sponge City success.

(a)

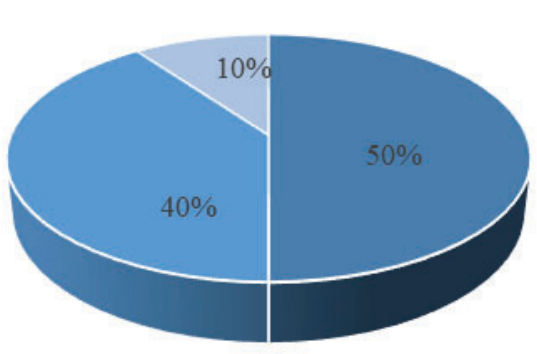

- Public-private partnership

- Local government

- Central Government (b)

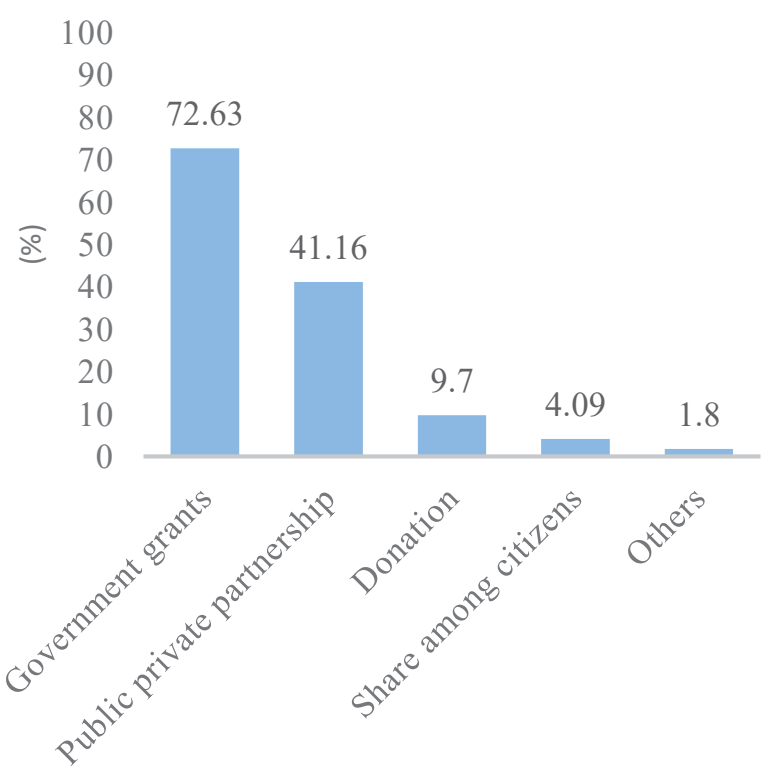

Figure 9. (a) Investments by different stakeholders in Sponge City projects from the Chinese government perspective, (b) the main sources for Sponge City projects from public perspectives (Adapted from Wang et al., 2017b.)

In 2014, China's Ministry of Housing and Urban-Rural Development published the technical guideline for Sponge City implementation (Li et al., 2016). The guideline focused on how to enhance conventional urban drainage with the objective of making water runoff from up to 1:30 year 24-h rainfall, in comparison with the runoff at 1:1 year rainstorm at the present (Chan et al., 2018). The guideline initially compared construction and maintenance costs of drainage infrastructure, in which rain garden, bio-swales, vegetation buffers were less expensive than artificial ponds and green roofs (Chan et al., 2018). After its issuance in 2015, the Sponge City program was proposed for pilot construction in 30 cities from which sixteen cities and fourteen cities were selected in 2015 and 2016, respectively. The management 
hierarchy of the Sponge City is classified as a shared responsibility between central government and local government (see Figure 10).

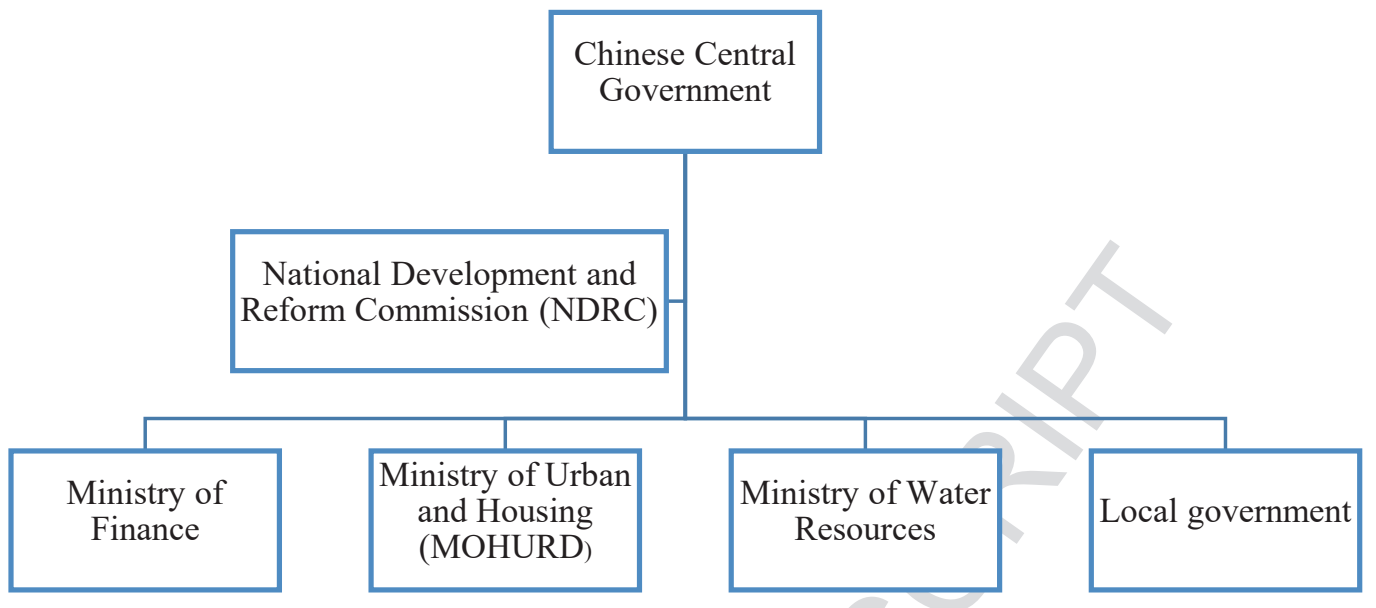

Figure 10. Chinese central government bodies involved in Sponge City implementation

The Chinese government is coordinating the work of other official bodies. The National Development and Reform Commission (NDRC) has been responsible for strengthening special financial support for Sponge City construction. The Ministry of Finance has allocated and generally managed funds for each area. The Ministry of Urban and Housing (MOHURD) has issued guidelines and standards for sponge city implementation as well as supervised pilot projects. The task of the Ministry of Water Resources is to supervise and guide Sponge Cities' water conservation aspects. Bodies that work at the local government level are responsible for planning and implementation of Sponge City projects in their jurisdictions. The close cooperation of various levels of government administration is a vital factor for successful implementation of Sponge City.

\section{Barriers and opportunities of Sponge City adoption}

\subsection{Barriers against adoption}

4.1.1. Technical and physical challenges 
China is encountering some major technical challenges in implementing the Sponge City. There are large technological discrepancies between developed and developing countries, where the latter have limited expertise or skills regarding green materials for green roofs or bio-detention, lack of technical guidance and training, outdated supportive simulation models, and insufficient performance data for planning and design matters. In addition, operation and maintenance difficulties and some physical challenges including climate, soil and geographical conditions are barriers to implementing a successful Sponge City.

Technical gaps and limitations that are evident in developing countries

The first overall problem is the technical gap between developed and developing countries, where the latter find it difficult to apply or accept technologies (Jia et al., 2017; Li et al., 2017; Li et al., 2016; Li et al., 2018; Ma et al., 2017; Xia et al., 2017a). Therefore, much more research has to be conducted on Sponge Cities in developing countries ( $\mathrm{Li}$ et al., 2017). All countries have their own distinctive geographical, climatic and soil conditions, so the design strategies implemented and the measures for construction need to be compatible with each location and or region, and should not be modelled incorrectly. Although the LID practices were introduced into China a decade ago, large-scale developments are still limited due to the lack of domestic and local research. In addition, urban water management technologies and the green infrastructure industry are much more advanced in wealthier countries, such as Germany, the U.K and the U.S. They have industries that can provide a range of green materials for green infrastructure building. Unfortunately, Sponge City products and materials such as green and blue modular, large-scale underground detention and monitoring equipment in China mainly come from abroad, which may be not suitable for local conditions. The unavailability and uncertainty of rain garden systems, green roof system, tree planter, infiltration planter system, underground infiltration and monitoring system, could undermine the whole rationale of the Sponge City program (Li et al., 2017; Xia et al., 2017). 
Lack of technical guidance and training

Although still in its pilot stage, Sponge City construction relies mainly on provincial and national guidelines for implementation, yet there is an issue here in that national guidelines only provide general advice while local guidelines emphasize technical issues. As the guidelines used are similar to the U.S. regarding best management practices and LID measures for urban water management, they do not pay attention to the varied conditions that exist throughout China, such as levels of runoff, climatic and soil conditions, etc. (Li et al., 2017; Ma et al., 2017). The major problem that contributes to Sponge City failure is the limited design strategies that encompass relevant standards and codes for diverse regions. Thus, each urban area should identify its own appropriate Sponge City measures (Association, 2017). Not all personnel involved are equipped with the essential knowledge about what a Sponge City actually needs, what the objectives are, and urban hydrology and hydraulics ranging from site scale to watershed (Jia et al., 2017). The lack of experts (architects, urban planners, hydraulic and environmental engineers, hydrogeologists, agronomists, etc.) to help build the Sponge City and limited educational and training courses for the up-skilling of local staff leads to inappropriate approaches and not successful outcomes.

$>$ Current and relevant simulation models for Sponge City design

To assist Sponge City planning and assessment the correct simulation model is required. Computer models apply a simulated design, policy, and strategy including widely used or accepted measures. Computer software modelling has the ability to consider various factors and environmental scenarios, for example: stormwater management in developed countries as part of the sustainable water management model (SWMM); stormwater quality model (SQM); and urban-water modelling software (MIKE-URBAN) (Bach et al., 2014). Enhanced models that can be adapted to the complex diverse urban water system variables in developing 
countries must produce a good fit and align well with the objectives of Sponge City purpose and mission.

Unavailable urban performance data

Creating a Sponge City is very complicated and many variable factors have to be accounted for: hydrology, land-use systems, urban development, and biodiversity (see Figure 11). All these aspects require evidence-based research. Performance of data for specific locations helps us to understand the range of climatic conditions and/or natural precipitation data, soil data, surface and groundwater characteristics, existing drainage systems and information on how buildings are constructed (Li et al., 2017; Shao et al., 2016). China currently has only limited regional data for Sponge City implementation. Without these input data, it is difficult to apply computer modelling for the Sponge City simulation, meaning that the outcomes of Sponge City construction cannot be accurately forecast. Thus, the lack of evidence becomes a hindrance to empowering people who, specifically, in the public to create change and participate in public-private partnerships supporting for SCP (Li et al., 2017; Wang et al., 2018). Furthermore, there are challenges due to the lack of knowledge compromising the ability to propose appropriate design strategies and measures for each urban area. 


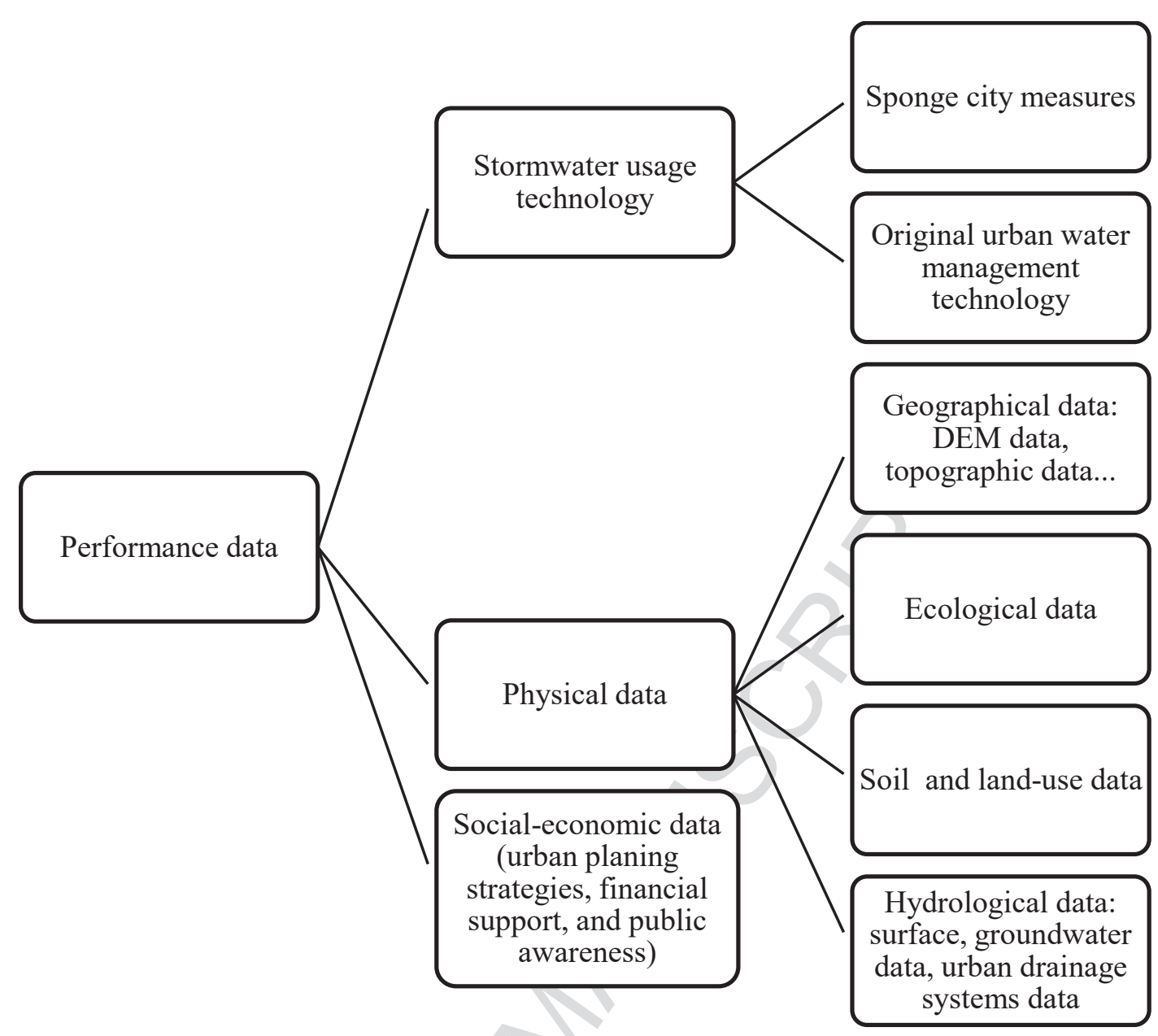

Figure 11. Required data for Sponge City design

\subsubsection{Financial challenges}

While Sponge City can be applied a simple low cost materials from LID and SUDS systems in small-scale, a completed Sponge City implementation at catchment scale requires substantial investment. Research on cost-benefit analysis of such projects is still limited, so the cost and benefit of Sponge City projects is difficult to compare. Liang (2018) conducted a project to assess the socio-economic and financial or investment aspects of Sponge City projects in the city of Chang-De in China. The project found that the environmental and social benefits of the Sponge City program should be encouraged by the government and the wider society. However, it determined that the private sector would not invest in a Sponge City project due to higher costs not being matched by higher revenues (Liang, 2018). As a result, the objective appears to be somewhat challenging in terms of the Chinese government 
attracting the investment of public-private partnerships, as this would require approximately $50 \%$ of total costs and may not be feasible. Nonetheless, this is only one scenario where the life cycle costs have to consider the design, construction costs, operation, maintenance costs, and compare them to the yet uncertain environmental, ecological and social benefits. Consequently, more research is required on the financial viability of Sponge City projects, in which life cycle benefits should be clearly articulated in terms of social wellbeing, return on investment, the value of private-public partnerships (PPP) and the role of local or regional organizations.

\subsubsection{Administrative fragmentation}

China's government administration system lacks cooperation between related functions or agencies (Jiang et al., 2017b; Li et al., 2017). As inter-connectedness is required to promote the Sponge City's aims for positive societal outcomes with urban planning, water management, land use and supporting eco-systems, so the value of community cooperation and the support from all levels of administration and agencies are essential for Sponge City construction. The complex nature of Sponge City implementation requires not only appropriate acceptance of technologies but also strong management systems and governance capabilities. The complex and fragmented structure of China's administrative system offers less opportunity for participation and collaboration between ministries, public/private sectors and local government bodies. Furthermore, the objectives of Sponge City may prove too difficult to achieve without a sense of collaboration and strong coordination between multiple stakeholders in sharing data, financial resources, etc. Having an appropriate legal framework or agency body that can ensure sharing of benefits between sectors will help cooperation and involvement of inter-agencies.

\subsubsection{Public awareness and acceptance challenges}


Community acceptance challenges is one of the strongest barriers against the adoption of Sponge City. Central government subsidies are inadequate due to the high and long-term funding requirement for construction. Therefore, the mobilization of non-government sources of finance is very important for Sponge City planning and building, especially when insufficient financial resources from the government make these sorts of projects difficult to achieve. China's central government and policy-makers have to recognize that in the longterm, the public-private partnership (PPP) strategy is the best way to make the Sponge City viable (Hodge and Greve, 2007; Zhang et al., 2018a). Improving public attitudes and perceptions of the Sponge City meet obstacles because the concept is still a very new one in China and the availability of information on public perceptions and willingness to pay for this ambitious project is still limited. Achieving public participation, people's willingness to invest, and having the education, training and information dissemination methods to support regions should be discussed with a broad array of public groups ranging from political leaders to everyday citizens ( $\mathrm{Li}$ et al., 2017; Wang et al., 2017b). The more people who understand its mission the more an urban community will adopt the Sponge City ethos. Ultimately, the benefits will reduce the dangers posed by urban flooding, lead to less pollution and mitigate water shortages.

\subsection{Opportunities}

Although the Sponge City idea was based on other concepts like LID, BMP, SUDS and WSUD, which have been implemented in developed countries, its objective is different. Its implementation is envisaged in terms of overcoming serious challenges in China in particular and in developing countries in general. Sponge City implementation not only has encountered some general challenges of other urban water management models, its implementation but also has associated distinct risks. The significant technical difficulties are 
the lack of an appropriate simulation model that includes the relevant factors based on evidence for implementing Sponge City designs. Local authorities simply imitate other cities' Sponge City plan that may not be suitable for their area. The second serious barrier is a monetary one in that building and maintaining a Sponge City requires a huge amount of finance, which the central government is reluctant to provide. It is important to attract funding from the public-private sector groups and international organizations. As well, the Chinese government must organize training courses for residents so that they understand the significance of the Sponge City. The successful implementation of the Sponge City program is based on four key aspects, which are illustrated in Figure 12.

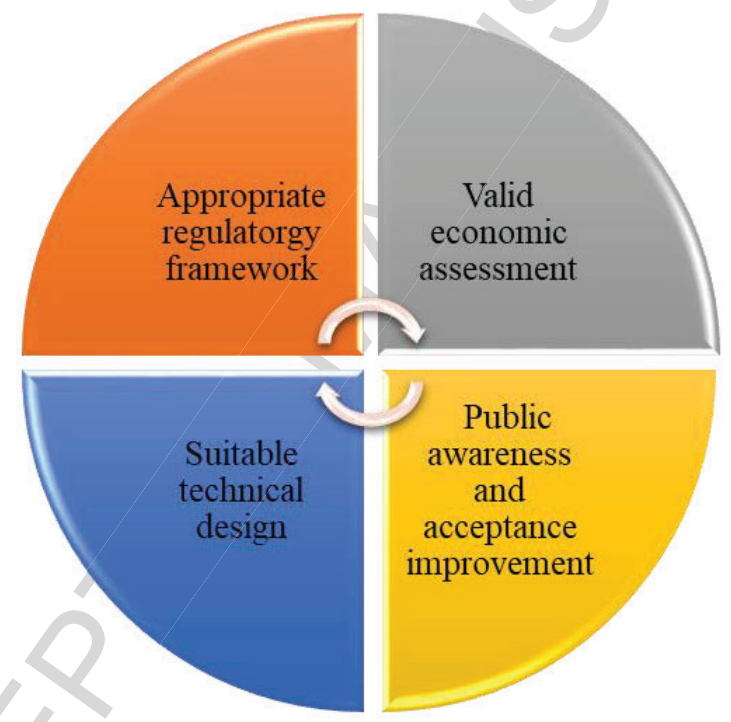

Figure 12. Key aspects to successful implementation of Sponge City

The various technical, physical financial, regulatory and community challenges of Sponge City program are summarized in Table 4 . The presence of these challenges can hinder the overall Sponge City implementation. 


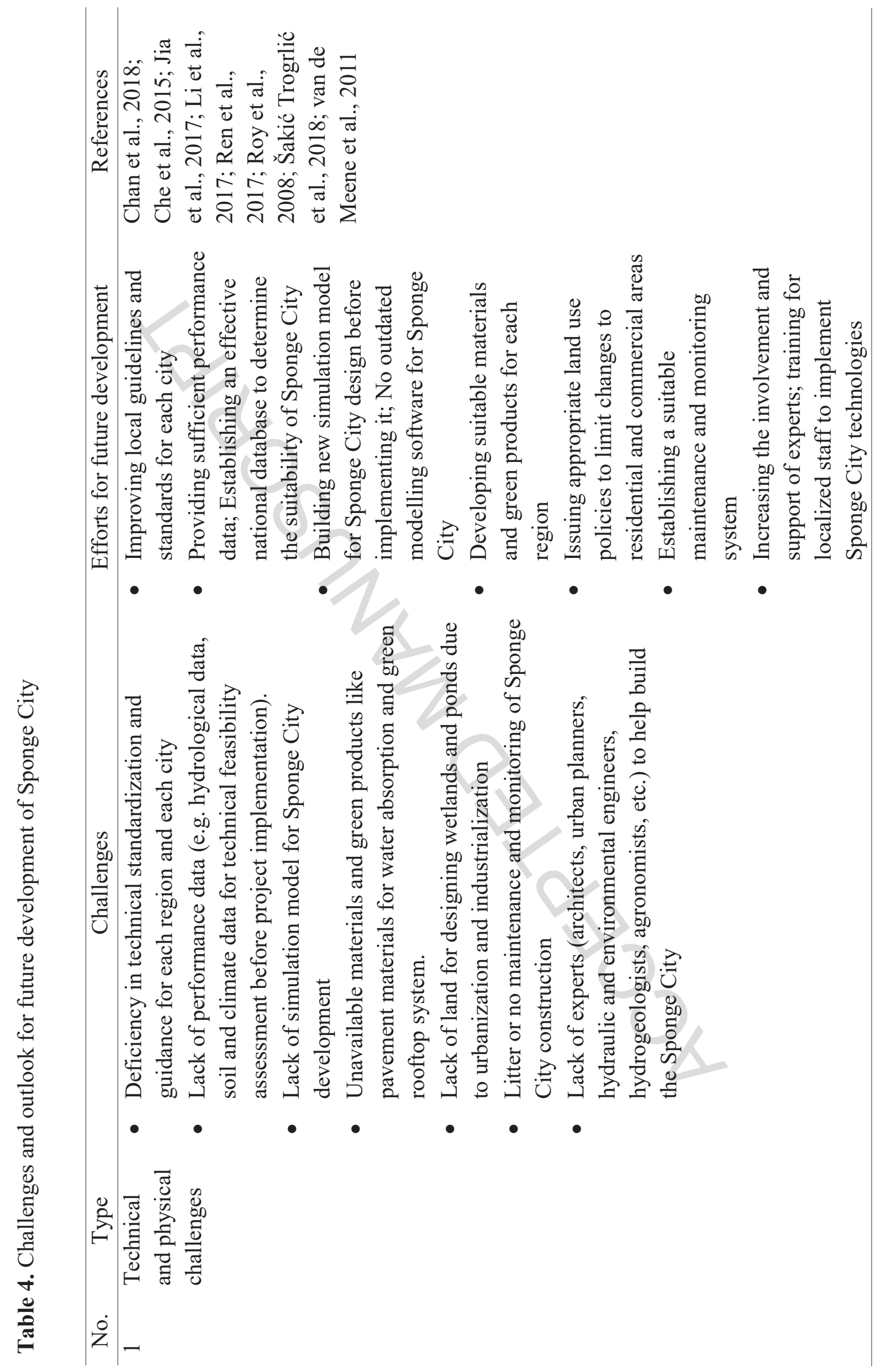




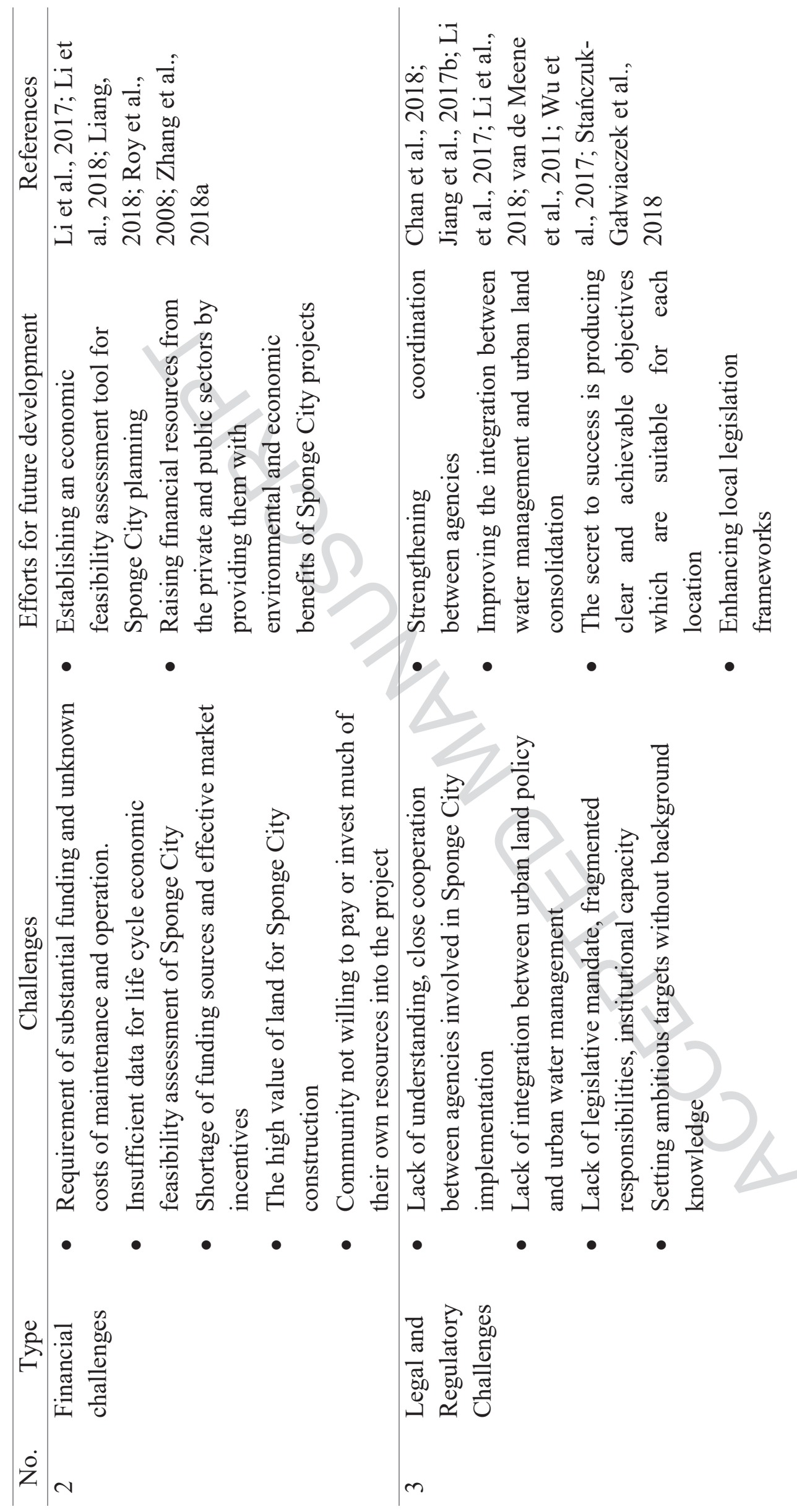




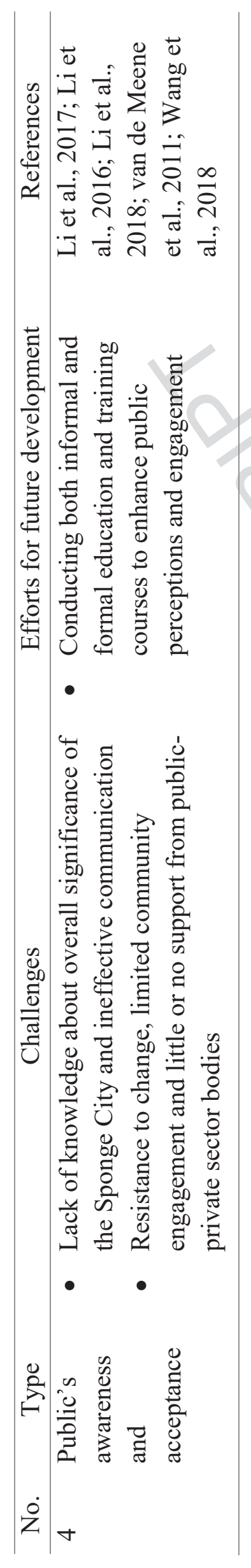




\section{Future perspectives}

5.1. Enhancing monitoring, evaluation system and promoting multi-channels cooperation management system

Sponge City projects require a systematic process of monitoring, evaluation and management (Hakimdavar et al., 2016). Prior to the construction, an integrated data system needs to collect information on: 1) suitable technologies; 2) identifying the investment sources and where the money is being allocated; 3) design and planning; and 4) evaluating the potential outcomes including the long-term effects and life cycle benefits (Jia et al., 2015). A long-term monitoring system should be implemented so that the Sponge City's functions for managing urban water supply and management are well understood. The results of proper evaluation and a long-term monitoring process will assist the development of Sponge City construction in other areas of China and elsewhere in the world. It is evident that many agencies will need to cooperate in order to share management data and avoid conflicts about aims, policies and benefits.

\subsection{Developing a decision support tool for sustainable implementation of Sponge City}

An appropriate simulation model is an indispensable method for supporting policy-makers, designers and builders in the construction of urban water drainage systems in watershed scales and continental scales (Bach et al., 2014; Stanchev and Ribarova, 2016; Golden \& Hoghooghi, 2018; Zhang \& Chui, 2019). Some urban stormwater models have already been developed and applied globally, for example SWMM, MIKE URBAN and Info-works CS (Bach et al., 2014), but these models may be not effective for solving many complex problems in Sponge City construction. The new model should be able to: firstly, predict the amount of urban rainfall-runoff with an understanding of complex surface characteristics of urban regions; secondly, simulate physical and chemical processes of green infrastructures in 
pollutants absorption and mitigation; and thirdly, forecast the ability of Sponge City management systems to prevent or minimize flooding. To ensure the Sponge City model works at its most effective, three major emerging problems must be addressed: (1) Online and physical tools need to be integrated and available for the sustainable urban water management model to work (Butler \& Schutze, 2005; Diaz-Granados et al., 2009), (2) the application of integrated models that pay real attention to tackling the range of uncertainties in their model (Liu et al., 2008); and (3) more investigations carried out on integrated models (Urich et al., 2013), in order to obtain longer time series simulation and higher integration levels.

\subsection{Valuing Sponge City Ecosystem Services}

Valuation of Sponge City ecosystem services can play a key role in raising the perceptions of public-private partnerships that this kind of project is viable. Sponge City implementation involves a range of values, including biophysical, economic, cultural and health values. All projects need to conduct a cost-benefit assessment and this involves, crucially, the public and private sectors (Toran, 2016). The assessment of cost-effectiveness of urban sponge projects encounters many obstacles due to the unknown maintenance and monitoring costs, and in calculating, the life cycle benefits related to social and ecological amenities (Liang, 2018; Mao et al., 2017; Association, 2017 ). Perceived benefits have to consider social and ecological amenities including biodiversity, recreation spaces, urban heat reduction, and healthier ecosystems, but these are difficult to quantify.

In addition, Sponge City implementation may have a positive effect on the value of properties located in or around the construction areas (Zhang et al., 2018a). Answering the question whether the Sponge City program will be cost-effective requires further analysis about economic benefits in a large-scale context (Chui et al., 2016). As well, different locations 
with varied hydrology, society and urban infrastructure will result in different outcomes and levels of success. Therefore, pilot projects and simulation scenarios may help identify the real costs involved and a more precise understanding of the benefits to all stakeholders. This results in increased public engagement and people's willingness to pay for Sponge City initiatives. To evaluate the benefits from ecological services and economic benefits of SUDS projects, the Construction Industry Research Information Association (CIRIA) in the United States was initiated W045 BeST (Benefits of SUDS Tool), which can estimate the overall advantages of SUDS practices versus existing urban water management practices. Sponge City projects can apply this tool for assessing their ecological services. However, the constraint of this tool is its difficulty in assessing the long-term benefits of Sponge City practices. This tool should incorporate to a Sponge City simulation model to account for any spatial and temporal changes in the future that may affect the performance of Sponge City infrastructure.

\subsection{Designing local guidelines and standards for Sponge City implementation}

Every urban area has its own hydrology, climate, soil and urban planning policy characteristics, and national laws or regulations may not necessarily be applicable to the local context. Understanding local conditions is the key to success in implementing the Sponge City concept. It is essential to develop localized regulations and standards based on evaluating carefully specific issues and potentials in each region. Inappropriate guidance and design from the central government to the provincial and local bureaucracies is causing problems in planning, design, construction, operation and evaluation of Sponge City projects. In addition, more engineering research into green infrastructure including bio-retention or green roofs should be conducted locally so that their new technologies can generate optimal benefits in flooding mitigation, pollution reduction, water absorption capacity and water filtration capacity. 
5.5. Promoting Sponge City construction in watershed scales based on integrated data development

In the long-term, a large-scale Sponge City should be built so that a range of urban waterrelated problems are addressed and solved. It is important to create a sustainable urban environment running parallel with more holistic social-economic development of urban areas. Moreover, the macro implementation of the Sponge City program needs to consider an integrated, watershed-scale approach and aim to connect the site, region and watershed scales. A macro implementation can potentially avoid the segmentation and isolation of the Sponge City system, maximize the benefits of ecosystem conservation, improve water quality, reduce flooding and create a healthy environment for people and wildlife living in the watershed.

\section{Conclusions}

The current urban water management framework needs to change in some countries like China. Sponge City is now deemed an innovative and revolutionary approach for addressing not only urban water problems but also enhancing ecological conditions and mitigating climate risks. It is more advantageous than traditional approaches. Sponge City has been found to be of great value for urban resilience. Despite its many benefits, the challenges for Sponge City construction remain and China needs to learn from similar concepts and developments in Western countries (e.g. BMPs, LID, SUDs and WSUD). More research is required to build a comprehensive computerized model for Sponge City design, identify appropriate technical measures including bio-detention systems, and green roofs. These are possibilities that can be applied in each locality. It is also important to improve co-ordination 
across government bureaucracies through the establishment of a Sponge City database system and experiences-sharing networks to deliver a successful, large-scale Sponge City model.

Finally, an economic valuation of Sponge City practices which highlights the whole life cycle benefits and risk of failure should be conducted to enhance public-private knowledge and perceptions. Doing so could enhance their willingness to support the implementation of the Sponge City and its sustainability features. Urban strategies and policies focused on promoting this concept play an important role in developing healthier, resilient and sustainable cities in an era of climate change and massive urbanization.

\section{Acknowledgements}

This review research was supported by the Centre for Technology in Water and Wastewater, University of Technology, Sydney (UTS, FEIT- RIA NGO)

\section{References}

Ashley, R., Lundy, L., Ward, S., Shaffer, P., Walker, L., Morgan, C., Saul, A., Wong, T., Moore, S. 2013. Water-sensitive urban design: opportunities for the UK. Proceedings of the Institution of Civil Engineers - Municipal Engineer, 166(2), 65-76.

Association, I.W. 2017. Sponge cities: Can China's model go global? in: International Water Association, The Source. China, pp. 4.

Bach, P.M., Rauch, W., Mikkelsen, P.S., McCarthy, D.T., Deletic, A. 2014. A critical review of integrated urban water modelling - Urban drainage and beyond. Environmental Modelling \& Software, 54, 88-107.

Besir, A.B., Cuce, E. 2018. Green roofs and facades: A comprehensive review. Renewable and Sustainable Energy Reviews, 82, 915-939.

Brown, R.R., Keath, N., Wong, T.H.F. 2009. Urban water management in cities: historical, current and future regimes. Water Science and Technology, 59(5), 847-855.

Brudermann, T., Sangkakool, T. 2017. Green roofs in temperate climate cities in Europe - An analysis of key decision factors. Urban Forestry \& Urban Greening, 21, 224-234.

Brunetti, G., Šimůnek, J., Piro, P. 2016. A comprehensive numerical analysis of the hydraulic behavior of a permeable pavement. Journal of Hydrology, 540, 1146-1161.

Burian, S., Edwards, F. 2002. Historical Perspectives of Urban Drainage. University of Utah, USA.

Butler, D., Schutze, M. 2005. Integrating simulation models with a view to optimal control of urban wastewater systems. Environmental Modelling \& Software, 20(4), 415-426. 
Campisano, A., Butler, D., Ward, S., Burns, M.J., Friedler, E., DeBusk, K., Fisher-Jeffes, L.N., Ghisi, E., Rahman, A., Furumai, H., Han, M. 2017. Urban rainwater harvesting systems: Research, implementation and future perspectives. Water Res, 115, 195-209.

Chan, F.K.S., Griffiths, J.A., Higgitt, D., Xu, S., Zhu, F., Tang, Y.-T., Xu, Y., Thorne, C.R. 2018. "Sponge City" in China-A breakthrough of planning and flood risk management in the urban context. Land Use Policy, DOI: 10.1016/j.landusepol.2018.03.005.

Chandana, D., H., G.M., C., P.K., Hillary, H., Andrea, R., William, S., M., Z.E. 2010. Simulation of Combined Best Management Practices and Low Impact Development for Sustainable Stormwater Management1. JAWRA Journal of the American Water Resources Association, 46(5), 907-918.

Che, W., Zhao, Y., Li, J.-q., Wang, W.-1., Wang, J.-1., Wang, S.-s., Gong, Y.-w. 2015. Explanation of Sponge City Development Technical Guide: Basic Concepts and Comprehensive Goals. China Water \& Wastewater, 31(8), 1-5.

Chen, H., Ma, J., Wei, J., Gong, X., Yu, X., Guo, H., Zhao, Y. 2018. Biochar increases plant growth and alters microbial communities via regulating the moisture and temperature of green roof substrates. Science of The Total Environment, 635, 333-342.

Chen, X.-1., Zhao, D.-q., Sheng, Z., Luo, R. 2015. Development and Application of Sponge City Planning System. China Water \& Wastewater, 31(19), 121-125.

Chen, Y. 2016. Research on the Urban Planning Strategy from the Perspective of Sponge City. Revista Ibérica de Sistemas e Tecnologias de Informação(E12), 283-294.

Christian Amos, C., Rahman, A., Mwangi Gathenya, J. 2016. Economic Analysis and Feasibility of Rainwater Harvesting Systems in Urban and Peri-Urban Environments: A Review of the Global Situation with a Special Focus on Australia and Kenya. Water, 8(4).

Chui, T.F.M., Liu, X., Zhan, W. 2016. Assessing cost-effectiveness of specific LID practice designs in response to large storm events. Journal of Hydrology, 533, 353-364.

Coma, J., Pérez, G., Cabeza, L.F. 2018. Chapter 4.8 - Life Cycle Assessment of Green Roofs. in: Nature Based Strategies for Urban and Building Sustainability, (Eds.) G. Pérez, K. Perini, Butterworth-Heinemann, pp. 341-351.

Davis, A.P., Hunt, W.F., Traver, R.G., Clar, M. 2009. Bioretention technology: Overview of current practice and future needs. Journal of Environmental Engineering, 135(3), 109117.

Developer, A.W. 2007. Towards sustainable water stewardship. Anglian Water Developer Services.

Diaz-Granados, M., Rodríguez, J.P., Rodríguez, M.S., Penagos, J.C., Camacho, L.A., Achleitner, S., Maksimovic, C., McIntyre, N. 2009. Towards a Paradigm Shift in Urban Drainage Management and Modelling in Developing Countries. Revista de Ingeniería, 133-150.

Dong, G., Weng, B., Qin, T., Denghua, Y., Wang, H., Gong, B., Bi, W., Xing, Z. 2018. The Impact of the Construction of Sponge Cities on the Surface Runoff in Watersheds, China. Advances in Meteorology, 2018, 9. 
Dong, X., Guo, H., Zeng, S. 2017. Enhancing future resilience in urban drainage system: Green versus grey infrastructure. Water Research, 124, 280-289.

Fletcher, T.D., Shuster, W., Hunt, W.F., Ashley, R., Butler, D., Arthur, S., Trowsdale, S., Barraud, S., Semadeni-Davies, A., Bertrand-Krajewski, J.-L., Mikkelsen, P.S., Rivard, G., Uhl, M., Dagenais, D., Viklander, M. 2014. SUDS, LID, BMPs, WSUD and more - The evolution and application of terminology surrounding urban drainage. Urban Water Journal, 12(7), 525-542.

Fujita, S. 1997. Measures to promote stormwater infiltration. Water Science and Technology, 36(8), 289-293.

Golden, H.E., Hoghooghi, N. 2018. Green infrastructure and its catchment-scale effects: an emerging science. WIREs Water, 5(1), 1254.

Gómez-Baggethun, E., Gren, Å., Barton, D.N., Langemeyer, J., McPhearson, T., O'Farrell, P., Andersson, E., Hamstead, Z., Kremer, P. 2013. Urban Ecosystem Services. in: Urbanization, Biodiversity and Ecosystem Services: Challenges and Opportunities: A Global Assessment, (Eds.) T. Elmqvist, M. Fragkias, J, Goodness, B. Güneralp, P.J. Marcotullio, R.I. McDonald, S. Parnell, M. Schewenius, M. Sendstad, K.C. Seto, C. Wilkinson, Springer Netherlands. Dordrecht, pp. 175-251.

Hakimdavar, R., Culligan, P.J., Guido, A., McGillis, W.R. 2016. The Soil Water Apportioning Method (SWAM): An approach for long-term, low-cost monitoring of green roof hydrologic performance. Ecological Engineering, 93, 207-220.

Herbert, K. 1961. The city in history: Its origins, its transformations, and its prospects. By Lewis Mumford. Harcourt, Brace \& World, Inc., 750 Third Avenue, New York 17, 1961. IX, 657 pp. \$11.50. National Civic Review, 50(10), 568-569.

Hodge, A.T. 1992. Roman aqueducts \& water supply, (Ed.) L. Gerald Duckworth \& Co. Ltd.

Hodge, G.A., Greve, C. 2007. Public-Private Partnerships: An International Performance Review. Public Administration Review, 67(3), 545-558.

Hu, M., Zhang, X., Siu, Y., Li, Y., Tanaka, K., Yang, H., Xu, Y. 2018. Flood Mitigation by Permeable Pavements in Chinese Sponge City Construction. Water, 10(2).

Huang, J.J., Li, Y., Niu, S., Zhou, S.H. 2014. Assessing the performances of low impact development alternatives by long-term simulation for a semi-arid area in Tianjin, northern China. Water Science and Technology, 70(11), 1740-1745.

Ice, G. 2004. History of Innovative Best Management Practices Development and Its Role in Addressing Water Quality Limited Waterbodies.

Jia, H., Wang, Z., Zhen, X., Clar, M., Yu, S.L. 2017. China's sponge city construction: A discussion on technical approaches. Frontiers of Environmental Science \& Engineering, 11(4).

Jia, H., Yao, H., Tang, Y., Yu, S.L., Field, R., Tafuri, A.N. 2015. LID-BMPs planning for urban runoff control and the case study in China. Journal of Environmental Management, 149, 65-76.

Jiang, C., Li, J., Li, H., Li, Y., Chen, L. 2017a. Field Performance of Bioretention Systems for Runoff Quantity Regulation and Pollutant Removal. Water, Air, and Soil Pollution, 228(12). 
Jiang, Y., Zevenbergen, C., Fu, D. 2017b. Understanding the challenges for the governance of China's "sponge cities" initiative to sustainably manage urban stormwater and flooding. Natural Hazards, 89(1), 521-529.

Jiang, Y., Zevenbergen, C., Ma, Y. 2018. Urban pluvial flooding and stormwater management: A contemporary review of China's challenges and "sponge cities" strategy. Environmental Science \& Policy, 80, 132-143.

Jim, C.Y. 2017. An archaeological and historical exploration of the origins of green roofs. Urban Forestry \& Urban Greening, 27, 32-42.

Kamali, M., Delkash, M., Tajrishy, M. 2017. Evaluation of permeable pavement responses to urban surface runoff. Journal of Environmental Management, 187, 43-53.

Kumar, K., Kozak, J., Hundal, L., Cox, A., Zhang, H., Granato, T. 2016. In-situ infiltration performance of different permeable pavements in a employee used parking lot - A four-year study. Journal of Environmental Management, 167, 8-14.

Laurenson, G., Laurenson, S., Bolan, N., Beecham, S., Clark, I. 2013. Chapter Four - The Role of Bioretention Systems in the Treatment of Stormwater. in: Advances in Agronomy, (Ed.) L.S. Donald, Vol. Volume 120, Academic Press, pp. 223-274.

Li, H., Ding, L., Ren, M., Li, C., Wang, H. 2017. Sponge City Construction in China: A Survey of the Challenges and Opportunities. Water, 9(12).

Li, X., Li, J., Fang, X., Gong, Y., Wang, W. 2016. Case Studies of the Sponge City Program in China. in: World Environmental and Water Resources Congress 2016, pp. 295-308.

Li, Z., Dong, M., Wong, T., Wang, J., Kumar, A., Singh, R. 2018. Objectives and Indexes for Implementation of Sponge Cities-A Case Study of Changzhou City, China. Water, 10(5), 623.

Liang, X. 2018. Integrated economic and financial analysis of China's Sponge City Program for water-resilient urban development. Sustainability (Switzerland), 10(3).

Liu, D. 2016. China\&\#39; s sponge cities to soak up rainwater. Nature, 537, 307.

Liu, J., Sample, D., Bell, C., Guan, Y. 2014. Review and Research Needs of Bioretention Used for the Treatment of Urban Stormwater. Water, 6(4), 1069-1099.

Liu, H., Jia, Y., Niu, C. 2017. "Sponge city" concept helps solve China's urban water problems. Environmental Earth Sciences, 76(14), 1-5.

Liu, L., Jensen, M.B. 2018. Green infrastructure for sustainable urban water management: Practices of five forerunner cities. Cities, 74, 126-133.

Liu, Y., Gupta, H., Springer, E., Wagener, T. 2008. Linking science with environmental decision making: Experiences from an integrated modeling approach to supporting sustainable water resources management. Environmental Modelling \& Software, 23(7), 846-858.

Liu, Y., Li, T., Peng, H. 2018. A new structure of permeable pavement for mitigating urban heat island. Sci Total Environ, 634, 1119-1125.

Liu, Y., Sun, C., Xu, S. 2013. Eco-Efficiency Assessment of Water Systems in China. Water Resources Management, 27(14), 4927-4939.

Ma, Z., Hu, J., Feng, P., Gao, Q., Qu, S., Song, W., Liu, J. 2017. Assessment of Climate Technology Demands in Chinese Sponge City. Journal of Geoscience and Environment Protection, 05(12), 102-116. 
Mangangka, I.R., Liu, A., Egodawatta, P., Goonetilleke, A. 2015. Performance characterisation of a stormwater treatment bioretention basin. Journal of Environmental Management, 150, 173-178.

Mao, X., Jia, H., Yu, S.L. 2017. Assessing the ecological benefits of aggregate LID-BMPs through modelling. Ecological Modelling, 353, 139-149.

Marlow, D.R., Moglia, M., Cook, S., Beale, D.J. 2013. Towards sustainable urban water management: a critical reassessment. Water Res, 47(20), 7150-61.

Mentens, J., Raes, D., Hermy, M. 2006. Green roofs as a tool for solving the rainwater runoff problem in the urbanized 21st century? Landscape and Urban Planning, 77(3), 217226.

Muthanna, T.M., Viklander, M., Blecken, G., Thorolfsson, S.T. 2007. Snowmelt pollutant removal in bioretention areas. Water Research, 41(18), 4061-4072.

Nkwunonwo, U.C., Whitworth, M., Baily, B. 2016. Review article: A review and critical analysis of the efforts towards urban flood risk management in the Lagos region of Nigeria. Natural Hazards and Earth System Sciences, 16(2), 349-369.

Pahl-Wostl, C. 2007. Transitions towards adaptive management of water facing climate and global change. Water Resources Management, 21(1), 49-62.

Qin, H.P., Li, Z.X., Fu, G. 2013. The effects of low impact development on urban flooding under different rainfall characteristics. J Environ Manage, 129, 577-85.

Randelovic, A., Zhang, K., Jacimovic, N., McCarthy, D., Deletic, A. 2016. Stormwater biofilter treatment model (MPiRe) for selected micro-pollutants. Water Research, 89, 180-191.

Ren, N., Wang, Q., Wang, Q., Huang, H., Wang, X. 2017. Upgrading to urban water system 3.0 through sponge city construction. Frontiers of Environmental Science \& Engineering, 11(4), 9.

Roy, A.H., Wenger, S.J., Fletcher, T.D., Walsh, C.J., Ladson, A.R., Shuster, W.D., Thurston, H.W., Brown, R.R. 2008. Impediments and solutions to sustainable, watershed-scale urban stormwater management: lessons from Australia and the United States. Environ Manage, 42(2), 344-59.

Rycewicz-Borecki, M., McLean, J.E., Dupont, R.R. 2017. Nitrogen and phosphorus mass balance, retention and uptake in six plant species grown in stormwater bioretention microcosms. Ecological Engineering, 99, 409-416.

Sailor, D.J. 2008. A green roof model for building energy simulation programs. Energy and Buildings, 40(8), 1466-1478.

Šakić Trogrlić, R., Rijke, J., Dolman, N., Zevenbergen, C. 2018. Rebuild by Design in Hoboken: A Design Competition as a Means for Achieving Flood Resilience of Urban Areas through the Implementation of Green Infrastructure. Water, 10(5).

Schaffer, D., Vollmer, D. 2010. Pathways to urban sustainability: Research and development on urban systems.

Scholz, M. 2006. Best management practice: A Sustainable Urban Drainage System management case study. Water International, 31(3), 310-319. 
Scholz, M., Uzomah, V.C. 2013. Rapid decision support tool based on novel ecosystem service variables for retrofitting of permeable pavement systems in the presence of trees. Science of The Total Environment, 458-460, 486-498.

Sedlak, D. 2014. Water 4.0: the Past, Present, and Future of the World's Most Vital Resource. Yale University Press, United State.

Shafique, M., Kim, R., Rafiq, M. 2018. Green roof benefits, opportunities and challenges - A review. Renewable and Sustainable Energy Reviews, 90, 757-773.

Shao, W., Zhang, H., Liu, J., Yang, G., Chen, X., Yang, Z., Huang, H. 2016. Data Integration and its Application in the Sponge City Construction of CHINA. Procedia Engineering. pp. 779-786.

Shi, T., Zhang, X., Du, H., Shi, H. 2015. Urban water resource utilization efficiency in China. Chinese Geographical Science, 25(6), 684-697.

Stanchev, P., Ribarova, I. 2016. Complexity, assumptions and solutions for eco-efficiency assessment of urban water systems. Journal of Cleaner Production, 138, 229-236.

Stańczuk-Gałwiaczek, M., Sobolewska-Mikulska, K., Ritzema, H., van Loon-Steensma, J.M. 2018. Integration of water management and land consolidation in rural areas to adapt to climate change: Experiences from Poland and the Netherlands. Land Use Policy, 77, 498-511.

Stovin, V. 2010. The potential of green roofs to manage Urban Stormwater. Water and Environment Journal, 24(3), 192-199.

Toran, L. 2016. Water Level Loggers as a Low-Cost Tool for Monitoring of Stormwater Control Measures. Water, 8(8), 346.

Trowsdale, S.A., Simcock, R. 2011. Urban stormwater treatment using bioretention. Journal of Hydrology, 397(3-4), 167-174.

Urich, C., Bach, P.M., Sitzenfrei, R., Kleidorfer, M., McCarthy, D.T., Deletic, A., Rauch, W. 2013. Modelling cities and water infrastructure dynamics. Proceedings of the Institution of Civil Engineers - Engineering Sustainability, 166(5), 301-308.

Van de Meene, S.J., Brown, R.R., Farrelly, M.A. 2011. Towards understanding governance for sustainable urban water management. Global Environmental Change, 21(3), 11171127.

Wang, H., Mei, C., Liu, J.H., Shao, W.W. 2018. A new strategy for integrated urban water management in China: Sponge city. Science China Technological Sciences, 61(3), 317-329.

Wang, M., Zhang, D., Adhityan, A., Ng, W.J., Dong, J., Tan, S.K. 2016. Assessing costeffectiveness of bioretention on stormwater in response to climate change and urbanization for future scenarios. Journal of Hydrology, 543, Part B, 423-432.

Wang, S., Lin, X., Yu, H., Wang, Z., Xia, H., An, J., Fan, G. 2017a. Nitrogen removal from urban stormwater runoff by stepped bioretention systems. Ecological Engineering, 106, Part A, 340-348.

Wang, Y., Sun, M., Song, B. 2017b. Public perceptions of and willingness to pay for sponge city initiatives in China. Resources, Conservation and Recycling, 122, 11-20.

Woods Ballard, B., Wilson, S., Udale-Clarke, H., Illman, S., Scott, T., Ashley, R., Kellagher, R. 2015. The SuDS Manual, C753. CIRIIA. 
Wu, W.-H., Wang, S.-S., Li, J.-Q., Xin, J.-G., Zhang, Z.-M., Liu, C. 2017. Discussion on Key Technical Issues of the Sponge City Implementation Program:A Case Study of Ningbo City. China Water \& Wastewater(6).

Wu, Y. 2015. Sponge City Design: Concept, Technology \& Case Study. Jiangsu: Phoenix Science Press.

Xia, J., Shi, W., Wang, Q., Zou, L. 2017a. Discussion of several hydrological issues regarding sponge city construction. Water Resources Protection, 33(1), 1-8.

Xia, J., Zhang, Y., Xiong, L., He, S., Wang, L., Yu, Z. 2017b. Opportunities and challenges of the Sponge City construction related to urban water issues in China. Science China Earth Sciences, 60(4), 652-658.

Yu, M.M., Zhu, J.W., Gao, W.F., Xu, D.P., Zhao, M. 2017. Urban permeable pavement system design based on "sponge city" concept. IOP Conference Series: Earth and Environmental Science, 82.

Zhang, K., Chui, T.F.M. 2019. Linking hydrological and bioecological benefits of green infrastructures across spatial scales - A literature review. Science of The Total Environment, 646, 1219-1231.

Zhang, S., Zevenbergen, C., Rabé, P., Jiang, Y. 2018a. The Influences of Sponge City on Property Values in Wuhan, China. Water, 10(6).

Zhang, W., Che, W. 2016. Connotation and multi-angle analysis of sponge city construction. Water Resources Protection, 32(6).

Zhang, X., Shen, L., Wu, Y. 2011. Green strategy for gaining competitive advantage in housing development: a China study. Journal of Cleaner Production, 19(2), 157-167.

Zhang, Z., Szota, C., Fletcher, T.D., Williams, N.S.G., Werdin, J., Farrell, C. 2018b. Influence of plant composition and water use strategies on green roof stormwater retention. Science of The Total Environment, 625, 775-781. 